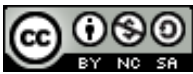

https://doi.org/10.31743/abmk.9601

ROMAN PELCZAR* - RZESZÓW

\title{
PRYWATNE ZAKLADY KSZTALCENIA I WYCHOWANIA DZIEWCZĄT W GALICJI W LATACH 1841-1870 (W ŚWIETLE DIECEZJALNYCH SZEMATYZMÓW SZKÓŁ LUDOWYCH)
}

\section{Streszczenie}

Celem artykułu jest ukazanie problemu edukacji dziewcząt z rodzin szlacheckich i mieszczańskich mieszkających w Galicji w XIX wieku. Często wysyłano je do prywatnych placówek edukacyjnych otwieranych w większych miastach tego obszaru. Chociaż problem dotyczy zaboru austriackiego, można go również rozpatrywać w kontekście pozostałych ziem polskich w czasie zaborów. Do opracowania artykułu wykorzystano głównie drukowane diecezjalne wykazy (szematyzmy) szkół ludowych z terenu Galicji. Przeanalizowano placówki edukacyjne dla dziewcząt prowadzone przez osoby prywatne. Większość zakładów tego typu powstała we Lwowie. Okres ich działalności był bardzo zróżnicowany. Organizatorami i właścicielami tych placówek były kobiety. Ponadto pełniły one funkcję nauczycielek. Najczęściej nauczały samodzielnie. Tylko czasami w niektórych zakładach zatrudniano dodatkowych nauczycieli. Powszechną praktyką było zatrudnianie do nauczania religii katolickiej miejscowych księży. Do tych instytucji przyjmowano nieduże grupy dziewcząt. Zazwyczaj było ich kilkanaście lub niewiele więcej.

Słowa kluczowe: szkoły dla dziewcząt; szkolnictwo w Galicji; edukacja dziewcząt; schematyzmy; Galicja

* Roman Pelczar - prof. dr hab. nauk humanistycznych, Instytut Pedagogiki, Uniwersytet Rzeszowski

e-mail: rpelczar@poczta.fm

https://orcid.org/0000-0002-0612-0009 


\section{Wstęp}

W polskiej literaturze naukowej, dotyczącej oświaty elementarnej na ziemiach zaboru austriackiego do czasu rozpoczęcia działalności przez Radę Szkolną Krajową (dalej: RSK) w 1868 r., można znaleźć wiele publikacji na temat różnych typów szkół. Natomiast naukowcy zupełnie pominęli kwestię konwiktów (pensji) i szkół prywatnych, otwieranych w tym czasie w większych miastach Galicji w celu edukacji dziewcząt $\mathrm{z}$ bogatszych rodzin szlacheckich i mieszczańskich. Dlatego celem niniejszego artykułu jest (przynajmniej częściowo) wypełnić tę lukę historyczną. W pracy prezentowane jest ujęcie statystyczne i ilościowe, na co pozwolił rodzaj wykorzystanych źródeł drukowanych w postaci diecezjalnych szematyzmów szkół ludowych. Dla dziejów oświaty elementarnej w Galicji do ukonstytuowania się RSK stanowi najwartościowszy rodzaj źródeł drukowanych. Jedną z zalet szematyzmów jest to, iż wydawano je systematycznie, często corocznie (jak miało to miejsce w przypadku diecezji przemyskiej oraz tarnowskiej). Poza tym cechuje je duża szczegółowość informacji. Dzięki temu można odtworzyć dość dokładny obraz analizowanych zagadnień, niemożliwy do uzyskania przy wykorzystaniu innych dokumentów z tego okresu. Do zredagowania artykułu wykorzystano informacje zawarte w szematyzmach szkół ludowych rzymskokatolickich diecezji z terenu Galicji, czyli lwowskiej, przemyskiej i tarnowskiej. W opracowaniu pominięto obszar Rzeczypospolitej Krakowskiej (od 1846 r. Wielkiego Księstwa Krakowskiego) ze względu na specyfikę jego historycznych losów oraz fakt, iż formalnie nie należał on do Galicji. Wchodził on w granice diecezji krakowskiej. Ponadto jej szematyzmy nie zawierały informacji na temat analizowanych placówek.

Chronologicznie artykuł obejmuje przedział czasowy od 1841 do 1870 r. Data początkowa wynika $\mathrm{z}$ faktu pojawienia się pierwszej informacji na ten temat w szematyzmie diecezji przemyskiej na rok szkolny 1841/1842. Datę końcową zdeterminowało parę względów. Pierwszy - to zmiany organizacyjne w oświacie galicyjskiej spowodowane przekazaniem w $1868 \mathrm{r}$. dotychczasowego nadzoru nad szkolnictwem elementarnym i średnim w Galicji (sprawowanego do tego czasu przez władze kościelne) w ręce RSK. Drugi - to konsekwencja powyższych zmian, co w końcu lat 60 . XIX wieku doprowadziło do zaprzestania wydawania przez władze poszczególnych diecezji szematyzmów szkół ludowych. Jako ostatnia uczyniła to w 1869 r. diecezja tarnowska, publikując jeszcze szematyzm na rok szkolny 1869/1870.

W opracowaniu analizie poddano prywatne zakłady kształcenia i wychowania dziewcząt prowadzone przez osoby fizyczne. Tworzono je w większych miastach Galicji. Natomiast pominięto podobne placówki organizowane przez rzymskokatolickie zakony żeńskie. Powstawały one sporadycznie. W szematyzmach szkół ludowych znaleźć można informacje tylko na temat jednego z takich zakładów (o statusie konwiktu szlacheckiego). Powstał on we Lwowie w 1787 r. za zgodą cesarza Józefa II, a w 1843 r. podniesiono go do rzędu konwiktów publicznych. Jego prowadzeniem zajmowały się siostry sakramentki. Z powyższych informacji wynika, że tworzeniem analizowanych zakładów kształcąco-wychowawczych zajmowały się zasadniczo jedynie osoby prywatne. 


\section{Sieć konwiktów i szkół dla dzieweząt w Galicji}

Rozpoczynając omawianie tematu, należy dokonać wyjaśnień terminologicznych odnośnie do rodzajów prywatnych zakładów kształcenia dziewcząt. W XIX wieku najczęściej posługiwano się terminem pensja. W myśl ówczesnych pojęć była to płatna szkoła dla dziewcząt, zazwyczaj z bursą, chociaż niekiedy uczennice dochodziły na naukę $\mathrm{z}$ miasta. W ramach czesnego wychowanki otrzymywały wikt oraz wszelkie potrzebne świadczenia związane z pobytem i nauką. Za pensje uznawano więc zakłady internatowe, na których działanie zgodę musiały wydać stosowne władze państwowe ${ }^{1}$. Dość powszechnie w źródłach z tego okresu pojęcie pensja zastępowano określeniem konwikt. Tak było w przypadku analizowanych szematyzmów szkół ludowych. Warto zauważyć, że istniała różnica między pensją (konwiktem) i klasyczną szkołą dla dziewcząt. Pierwsza była miejscem, w którym je uczono i wychowywano oraz gdzie równocześnie mieszkały. Natomiast szkoła była wyłącznie miejscem pobierania nauki, do której panny przychodziły w konkretnych godzinach na zajęcia edukacyjne ${ }^{2}$.

Na ziemiach polskich po raz pierwszy kwestię kształcenia dziewcząt próbowała podjąć Komisja Edukacji Narodowej (dalej: KEN). Za najbardziej palący problem uznała ona kształcenie panien z warstw zamożnych w prywatnych zakładach edukacyjno-wychowawczych (pensjach). Autorem jednego z projektów dotyczącego tej sprawy, przesłanym do KEN, był Franciszek Bieliński. Największy udział w opracowaniu zasad kształcenia i wychowania w zakładach tego typu miał jednak Adam Kazimierz Czartoryski, autor przepisów organizacyjnych adresowanych do właścicielek pensji, przygotowanych na polecenie KEN ${ }^{3}$. Do kwestii edukacji dziewcząt powracano także w początkach XIX wieku, już w czasach zaborów. Jedną z osób snujących plany kształcenia panien był Tadeusz Czacki, który pracując w 1803 r. nad projektem Gimnazjum Wołyńskiego w Krzemieńcu, planował utworzenie przy nim Instytutu Guwernantek. Koncepcję tę podjął i poparł Hugo Kołłątaj. Jednak ostatecznie zakład ten nie powstał. Do tego projektu nawiązały później władze Królestwa Polskiego, organizując w 1825 r. Instytut Guwernantek w Warszawie ${ }^{4}$.

Jak wynika z powyższych informacji, także w początkach XIX wieku na ziemiach polskich zaczęto poszukiwać rozwiązania problemu kształcenia córek ziemiańskich oraz bogatego mieszczaństwa. Dla tych pierwszych edukacja stanowiła wymóg życia towarzyskiego, a dla drugich stawała się niezbędna do podjęcia w przyszłości pracy zawodowej. Innym ówczesnym motywem edukacji dziew-

\footnotetext{
${ }^{1}$ K. Dormus, A. Włoch, J. Wojniak, Edukacja kobiet, kobiety w edukacji. Szkice historycznopedagogiczne, Kraków 2017, s. 27.

${ }^{2}$ J. Selingerowa, Obowiazki kobiety każdego stanu w zakresie gospodarstwa domowego, Lwów 1882, s. 3; M. Janicka, Edukacja kobiet na ziemiach polskich na przetomie XVIII i XIX wieku, Warszawa 2017, s. 128 (zamieszczona w Internecie praca doktorska), https://depotuw.ceon.pl/handle/ item/2527 (dostęp: 23.12.2019).

${ }^{3}$ Dormus, Włoch, Wojniak, Edukacja kobiet, s. 23-27.

${ }^{4}$ B. Wlaźlik, Historyczny wymiar edukacji dziewcząt, „Prace Naukowe Akademii im. Jana Długosza w Częstochowie". Seria: Pedagogika, 15 (2006) s. 211-214; Dormus, Włoch, Wojniak, Edukacja kobiet, s. 54-55.
} 
cząt z wymienionych środowisk społecznych było coraz bardziej popularne przekonanie o istotnym wpływie kobiet na wychowanie młodego pokolenia, jego postawy moralne $\mathrm{i}$ narodowe ${ }^{5}$. W tym czasie nie istniał przymus edukacji kobiet $\mathrm{z}$ rodzin szlacheckich w prywatnych pensjach (klasztornych lub świeckich), więc wiele dziewcząt, zwłaszcza z zamożniejszych domów, pobierało głównie (lub wyłącznie) naukę domową. Tę ostatnią formę edukacji dość powszechnie uznawano za najlepszą, a pensje przez niektórych uważane były wręcz za szkodliwe dla procesu ich kształcenia i wychowania ${ }^{6}$.

Równocześnie dokonywała się zmiana społecznego zapatrywania na potrzebę kształcenia dziewcząt z „,dobrych domów”, a co za tym idzie - na rozwój edukacji żeńskiej. Przyczyniło się to do powstawania na przełomie XVIII i XIX wieku licznych pensji panieńskich. Instytucje te charakteryzowały się indywidualnymi programami nauczania i odrębnymi regulaminami funkcjonowania. Nauka i wychowanie odbywały się $\mathrm{w}$ kategoriach praktycznych. Nie zawsze nauczycieli cechował zbiór najwyższych cnót moralnych:

Owi pensjomistrze, licząc się z modą ówczesną, dbali jedynie o to, aby młodą pannę obdarzyć jak największym powabem towarzyskim, rozlicznymi „talentami”, płynną francuszczyzną i tańcem, hodując społeczeństwu „cudzoziemki” w swoim własnym kraju?

Celem takiego sposobu kształcenia było zdobywanie przez pensjonarki polotu towarzyskiego i ćwiczenie tzw. talentów, czyli tańca, muzyki, niekiedy rysunków, wytwornych manier towarzyskich i światowych obyczajów ${ }^{8}$.

Tradycja tworzenia prywatnych konwiktów i szkół dla dziewcząt z rodzin szlachty oraz bogatego mieszczaństwa na terenie Rzeczypospolitej sięga jeszcze XVI wieku, z tym że były to placówki organizowane wyłącznie przez klasztory żeńskie. Zakłady tego typu tworzono także w okresie rozbiorów we wszystkich trzech zaborach. Jednak wtedy tę inicjatywę zaczęły podejmować także osoby prywatne. Pobyt w takich konwiktach był drogi, dlatego też na kształcenie córek pozwalało sobie niewiele rodzin. Wysokość opłaty za pobyt była zróżnicowana i zależała od standardu placówki ${ }^{9}$.

W Galicji pierwsze prywatne zakłady kształcenia dziewcząt ze stanu szlacheckiego otworzono we Lwowie - stolicy tej prowincji Austrii. Niestety, nie odnaleziono informacji na temat czasu powstania najstarszych tego typu placówek. Wiadomo jedynie, że prywatna szkoła dla dziewcząt przed 1829 r. znajdowała się w konwikcie dla córek szlacheckich u sióstr sakramentek. Oprócz tego kilka osób utrzymywało konwikty i pensje, gdzie panny doskonaliły się w naukach i zajęciach „właściwych swemu stanowi społecznemu”"10. Przed $1841 \mathrm{r}$.

${ }^{5}$ M. Dobrowolska, Początki szkolnictwa dla dziewczat, w: Historia wychowania, red. Ł. Kurdybacha, t. 2, Warszawa 1967, s. 189-190.

${ }^{6}$ Pensja, http://czasemancypantek.pl/w-spoleczenstwie/edukacja/36-pensja (dostęp: 10.04.2020).

${ }^{7}$ B. Zięba-Kołodziej, Internat i bursa. Historia i współczesność, Tarnobrzeg 2011, s. 18.

${ }^{8}$ Cyt. za tamże, s. 18.

${ }^{9}$ Tamże, s. 21.

${ }^{10}$ I. Chodynicki, Historia stołecznego królestw Galicji i Lodomeryi miasta Lwowa od założenia jego aż do czasów teraźnieyszych, Lwów 1829, s. 408. 
W mieście (oprócz konwiktu sakramentek) było 5 takich prywatnych zakładów ${ }^{11}$. Szczegółowe informacje na temat lwowskich placówek kształcenia panien z rodzin ziemiańskich udało się odnaleźć jednak dopiero w szematyzmach szkół ludowych łacińskiej archidiecezji lwowskiej dla lat 60. XIX wieku. Ówczesną sieć prywatnych konwiktów i szkół żeńskich zaprezentowano w tabeli 1.

Tabela 1. Prywatne zakłady kształcenia dziewcząt na terenie lacińskiej archidiecezji lwowskiej w latach 1860-1867

\begin{tabular}{|c|c|c|c|c|}
\hline $\begin{array}{c}\text { Rok } \\
\text { szkolny }\end{array}$ & Miasto & $\begin{array}{c}\text { Wlaścicielka zakładu } \\
\text { edukacyjnego }\end{array}$ & $\begin{array}{l}\text { Rodzaj zakładu } \\
\text { edukacyjnego }\end{array}$ & Źródło \\
\hline 1 & 2 & 3 & 4 & 5 \\
\hline $1860 / 61$ & Stanisławów & $\begin{array}{l}\text { Honorata Bachotte } \\
\text { Elżbieta Ciesielska } \\
\text { Antonia Heindl } \\
\text { Barbara Lauer } \\
\text { Rozalia Lauer } \\
\text { Emilia Neugebauer } \\
\text { Józefa Riedl } \\
\text { Emma Schürrer } \\
\text { Justyna Świeprawska } \\
\text { Emilia Titz } \\
\text { Felicja Wasilewska } \\
\text { Bronisława Wierzbięta } \\
\text { Barbara Żinkowska } \\
\text { Anna Preyer } \\
\text { Filipina Nowakowska }\end{array}$ & $\begin{array}{l}\text { konwikt i szkoła } \\
\text { konwikt } \\
\text { szkoła } \\
\text { konwikt } \\
\text { konwikt i szkoła } \\
\text { konwikt i szkoła } \\
\text { konwikt i szkoła } \\
\text { konwikt i szkoła } \\
\text { konwikt i szkoła } \\
\text { konwikt i szkoła } \\
\text { konwikt i szkoła } \\
\text { konwikt i szkoła } \\
\text { konwikt i szkoła } \\
\text { konwikt } \\
\text { konwikt }\end{array}$ & $\begin{array}{l}\text { Szematyzm } \\
\text { (...) } 1861 \text {, } \\
\text { s. } 9,26\end{array}$ \\
\hline $1861 / 62$ & Stanisławów & $\begin{array}{l}\text { Honorata Bachotte } \\
\text { Antonia Heindl } \\
\text { Rozalia Lauer } \\
\text { Emilia Neugebauer } \\
\text { Józefa Riedl } \\
\text { Emma Schürrer } \\
\text { Justyna Świeprawska } \\
\text { Emilia Titz } \\
\text { Felicja Wasilewska } \\
\text { Bronisława Wierzbięta } \\
\text { Barbara Żinkowska } \\
\text { Anna Preyer } \\
\text { Filipina Nowakowska }\end{array}$ & $\begin{array}{l}\text { konwikt i szkoła } \\
\text { szkoła } \\
\text { konwikt i szkoła } \\
\text { konwikt i szkoła } \\
\text { konwikt i szkoła } \\
\text { konwikt i szkoła } \\
\text { konwikt i szkoła } \\
\text { konwikt i szkoła } \\
\text { konwikt i szkoła } \\
\text { konwikt i szkoła } \\
\text { konwikt i szkoła } \\
\text { konwikt } \\
\text { konwikt }\end{array}$ & $\begin{array}{l}\text { Szematyzm } \\
\text { (...) } 1862 \text {, } \\
\text { s. } 9,10,31\end{array}$ \\
\hline $1863 / 64$ & Lwów & $\begin{array}{l}\text { Honorata Bachotte } \\
\text { Antonia Heindl } \\
\text { Rozalia Lauer } \\
\text { Emilia Neugebauer }\end{array}$ & $\begin{array}{l}\text { konwikt i szkoła } \\
\text { szkoła } \\
\text { konwikt i szkoła } \\
\text { konwikt i szkoła }\end{array}$ & $\begin{array}{l}\text { Szematyzm } \\
\text { (...) } 1864 \text {, } \\
\text { s. } 9,10,34\end{array}$ \\
\hline
\end{tabular}

${ }^{11}$ M.W., Rys statystyczno-jeograficzny Galicyi Austrjackiej, Poznań 1842, s. 84. 


\begin{tabular}{|c|c|c|c|c|}
\hline 1 & 2 & 3 & 4 & 5 \\
\hline $1863 / 64$ & Lwów & $\begin{array}{l}\text { Józefa Riedl } \\
\text { Emma Schürrer } \\
\text { Justyna Świeprawska } \\
\text { Emilia Titz } \\
\text { Felicja Wasilewska } \\
\text { Bronisława Wierzbięta } \\
\text { Barbara Żinkowska } \\
\text { Anna Preyer } \\
\text { Franciszka Albrich } \\
\text { Emma Schor }\end{array}$ & $\begin{array}{l}\text { konwikt i szkoła } \\
\text { konwikt i szkoła } \\
\text { konwikt i szkoła } \\
\text { konwikt i szkoła } \\
\text { konwikt i szkoła } \\
\text { konwikt i szkoła } \\
\text { konwikt i szkoła } \\
\text { konwikt } \\
\text { konwikt } \\
\text { konwikt }\end{array}$ & $\begin{array}{l}\text { Szematyzm } \\
\text { (...) } 1864 \text {, } \\
\text { s. } 9,10,34\end{array}$ \\
\hline $1863 / 64$ & Stanisławów & $\begin{array}{l}\text { Honorata Bachotte } \\
\text { Antonia Heindl } \\
\text { Rozalia Lauer } \\
\text { Emilia Neugebauer } \\
\text { Józefa Riedl } \\
\text { Emma Schürrer } \\
\text { Justyna Świeprawska } \\
\text { Emilia Titz } \\
\text { Felicja Wasilewska } \\
\text { Bronisława Wierzbięta } \\
\text { Barbara Żinkowska } \\
\text { Anna Preyer } \\
\text { Franciszka Albrich } \\
\text { Emma Schor }\end{array}$ & $\begin{array}{l}\text { konwikt i szkoła } \\
\text { szkoła } \\
\text { konwikt i szkoła } \\
\text { konwikt i szkoła } \\
\text { konwikt i szkoła } \\
\text { konwikt i szkoła } \\
\text { konwikt i szkoła } \\
\text { konwikt i szkoła } \\
\text { konwikt i szkoła } \\
\text { konwikt i szkoła } \\
\text { konwikt i szkoła } \\
\text { konwikt } \\
\text { konwikt } \\
\text { konwikt }\end{array}$ & $\begin{array}{l}\text { Szematyzm } \\
\text { (...) } 1864, \\
\text { s. } 9,10,34\end{array}$ \\
\hline $1864 / 65$ & 更 & $\begin{array}{l}\text { Honorata Bachotte } \\
\text { Antonia Heindl } \\
\text { Rozalia Lauer } \\
\text { Emilia Neugebauer } \\
\text { Józefa Riedl } \\
\text { Emma Schürrer } \\
\text { Justyna Świeprawska } \\
\text { Emilia Titz } \\
\text { Bronisława Wierzbięta } \\
\text { Barbara Żinkowska } \\
\text { Anna Preyer } \\
\text { Franciszka Albrich } \\
\text { Emma Schor }\end{array}$ & $\begin{array}{l}\text { konwikt i szkoła } \\
\text { szkoła } \\
\text { konwikt i szkoła } \\
\text { konwikt i szkoła } \\
\text { konwikt i szkoła } \\
\text { konwikt i szkoła } \\
\text { konwikt i szkoła } \\
\text { konwikt i szkoła } \\
\text { konwikt i szkoła } \\
\text { konwikt i szkoła } \\
\text { konwikt } \\
\text { konwikt } \\
\text { konwikt }\end{array}$ & $\begin{array}{l}\text { Szematyzm } \\
\text { (...) } 1865, \\
\text { s. } 9,10,34\end{array}$ \\
\hline $1865 / 66$ & Lwów & $\begin{array}{l}\text { Honorata Bachotte } \\
\text { Izabela Ciesielska } \\
\text { Emilia Dimmel } \\
\text { Antonia Heindl } \\
\text { Rozalia Lauer } \\
\text { Emilia Neugebauer } \\
\text { Helena Pożakowska }\end{array}$ & $\begin{array}{l}\text { konwikt i szkoła } \\
\text { szkoła } \\
\text { konwikt i szkoła } \\
\text { szkoła } \\
\text { konwikt i szkoła } \\
\text { konwikt i szkoła } \\
\text { szkoła }\end{array}$ & $\begin{array}{l}\text { Szematyzm } \\
\text { (...) } 1866 \text {, } \\
\text { s. } 9,10,33 \text {, } \\
37\end{array}$ \\
\hline
\end{tabular}




\begin{tabular}{|c|c|c|c|c|}
\hline 1 & 2 & 3 & 4 & 5 \\
\hline $1865 / 66$ & $\begin{array}{l}\text { Stanisławów } \\
\text { Kołomyja }\end{array}$ & $\begin{array}{l}\text { Emma Schürrer } \\
\text { Teresa Wentz } \\
\text { Fryderyka Wiethe } \\
\text { Barbara Żinkowska } \\
\text { Anna Preyer } \\
\text { Franciszka Albrich } \\
\text { Leokadia Panatowska }\end{array}$ & $\begin{array}{l}\text { konwikt i szkoła } \\
\text { konwikt i szkoła } \\
\text { konwikt i szkoła } \\
\text { konwikt i szkoła } \\
\text { konwikt } \\
\text { konwikt } \\
\text { konwikt }\end{array}$ & $\begin{array}{l}\text { Szematyzm } \\
\text { (...) } 1866 \text {, } \\
\text { s. } 9,10,33 \text {, } \\
37\end{array}$ \\
\hline $1866 / 67$ & $\begin{array}{l}\text { Stanisławów } \\
\text { Kołomyja }\end{array}$ & $\begin{array}{l}\text { Honorata Bachotte } \\
\text { Izabela Ciesielska } \\
\text { Emilia Dimmel } \\
\text { Antonia Heindl } \\
\text { Teresa Śmiałowska } \\
\text { Emilia Neugebauer } \\
\text { Helena Pożakowska } \\
\text { Emma Schürrer } \\
\text { Teresa Wentz } \\
\text { Barbara Żinkowska } \\
\text { Anna Preyer } \\
\text { Franciszka Albrich } \\
\text { Leokadia Panatowska }\end{array}$ & $\begin{array}{l}\text { konwikt i szkoła } \\
\text { szkoła } \\
\text { konwikt i szkoła } \\
\text { szkoła } \\
\text { szkoła } \\
\text { konwikt i szkoła } \\
\text { szkoła } \\
\text { konwikt i szkoła } \\
\text { konwikt i szkoła } \\
\text { konwikt i szkoła } \\
\text { konwikt } \\
\text { konwikt } \\
\text { konwikt }\end{array}$ & $\begin{array}{l}\text { Szematyzm } \\
\text { (...) } 1867, \\
\text { s. } 10,33,37\end{array}$ \\
\hline
\end{tabular}
passim.

Źródło: Szematyzmy szkót ludowych archidiecezji lwowskiej obrz. tac. na lata 1861-1867,

W przypadku tej archidiecezji dostępne są więc jedynie częściowe dane statystyczne odnośnie do liczby zakładów kształcenia panien i to tylko dla ostatniego dziesięciolecia omawianego okresu. Na podstawie tych zestawień (tabela 2) można zuważyć, że na tym terenie łącznie działały wtedy 23 zakłady kształcenia dziewcząt (18 we Lwowie, 4 w Stanisławowie i 1 w Kołomyi). Istniały więc zaledwie w trzech miastach. Duża liczba placówek we Lwowie wynikała z jego stołecznej roli w Galicji. Biorąc za podstawę wniosków lata 60. XIX wieku, można stwierdzić, iż pensje zazwyczaj funkcjonowały po kilka lat i po tym czasie zawieszały pracę. Aż 9 szkół istniało w okresie zaledwie od roku do dwóch lat. Jedynymi, które funkcjonowały przez cały okres uwzględniony przez szematyzmy szkolne tej archidiecezji (czyli lata 1860-1867), były konwikty H. Bachotte i B. Żinkowskiej. Równie długo (7 lat) działał konwikt A. Preyer w Stanisławowie. 
Tabela 2. Okres istnienia prywatnych żeńskich zakładów edukacyjnych w miastach lacińskiej archidiecezji lwowskiej w latach 1860-1867

\begin{tabular}{|l|l|l|c|}
\hline \multicolumn{1}{|c|}{ Miasto } & \multicolumn{1}{|c|}{$\begin{array}{c}\text { Wlaścicielka zakładu } \\
\text { edukacyjnego }\end{array}$} & $\begin{array}{c}\text { Lata szkolne } \\
\text { lat }\end{array}$ \\
\hline & Honorata Bachotte & $1860 / 61-1866 / 67$ & 7 \\
& Elżbieta Ciesielska & $1860 / 61$ & 1 \\
& Antonia Heindl & $1860 / 61-1866 / 67$ & 7 \\
& Barbara Lauer & $1860 / 61$ & 1 \\
& Rozalia Lauer & $1860 / 61-1865 / 66$ & 6 \\
& Emilia Neugebauer & $1860 / 61-1866 / 67$ & 7 \\
& Józefa Riedl & $1860 / 61-1864 / 65$ & 5 \\
& Emma Schürrer & $1860 / 61-1866 / 67$ & 7 \\
& Justyna Świeprawska & $1860 / 61-1864 / 65$ & 5 \\
& Emilia Titz & $1860 / 61-1864 / 65$ & 5 \\
& Felicja Wasilewska & $1860 / 61-1863 / 64$ & 4 \\
& Bronisława Wierzbięta & $1860 / 61-1864 / 65$ & 5 \\
& Barbara Żinkowska & $1860 / 61-1866 / 67$ & 7 \\
& Izabela Ciesielska & $1865 / 66-1866 / 67$ & 2 \\
& Emilia Dimmel & $1865 / 66-1866 / 67$ & 2 \\
& Helena Pożakowska & $1865 / 66-1866 / 67$ & 2 \\
& Teresa Wentz & $1865 / 66-1866 / 67$ & 2 \\
& Fryderyka Wiethe & $1865 / 66$ & 1 \\
\hline Kołomyja & Anna Preyer & $1860 / 61-1866 / 67$ & 7 \\
& Filipina Nowakowska & $1860 / 61-1861 / 62$ & 2 \\
& Franciszka Albrich & $1863 / 64-1866 / 67$ & 4 \\
\hline \multirow{5}{*}{ Stanisławów } & Emma Schor & $1863 / 64-1864 / 65$ & 2 \\
\hline & Leokadia Panatowska & $1865 / 66-1866 / 67$ & 2 \\
\hline
\end{tabular}

Źródło: Szematyzmy szkót ludowych archidiecezji lwowskiej obrz. łac. na lata 1861-1867, passim.

Analiza tabel 1 i 2 dowodzi dużej płynności w zakresie liczby konwiktów i szkół w wyżej wymienionych miastach (nawet w przypadku Lwowa).

Analogiczne zakłady edukacyjne tworzono także w łacińskiej diecezji przemyskiej. Stosownych informacji na ich temat dostarczyły szematyzmy szkół ludowych. Najstarsza wiadomość zamieszczona została w roczniku 1841/1842 (tabela 3). Uwzględniono w nim konwikt M. Pichy w Rzeszowie. W roku następnym pojawiła się pensja T. Brettner w Przemyślu. Przez kilka kolejnych lat były to jedyne placówki tego typu w diecezji. Od roku szkolnego 1847/1848 w szematyzmach nie ujmowano Rzeszowa. Ponownie pensje w tym mieście zaczęto uwzględniać od roku szkolnego 1857/58. W międzyczasie powstały konwikty w Samborze i Jaśle. W latach 60. XIX wieku w szematyzmach nie był wymieniany już konwikt w Samborze. Pojawiły się natomiast nowe - w Przeworsku i Leżajsku. 
Tabela 3. Prywatne zakłady kształcenia dziewcząt na terenie lacińskiej diecezji przemyskiej w latach 1841-1868

\begin{tabular}{|c|c|c|c|c|}
\hline $\begin{array}{l}\text { Rok } \\
\text { szkolny }\end{array}$ & Miasto & $\begin{array}{c}\text { Właścicielka zakładu } \\
\text { edukacyjnego }\end{array}$ & $\begin{array}{c}\text { Liczba } \\
\text { uczennic }\end{array}$ & Źródło \\
\hline 1 & 2 & 3 & 4 & 6 \\
\hline $1841 / 42$ & Rzeszów & Maria Picha & 19 & $\begin{array}{l}\text { Szematyzm (...) 1842, } \\
\text { s. } 11\end{array}$ \\
\hline $1842 / 43$ & $\begin{array}{l}\text { Przemyśl } \\
\text { Rzeszów }\end{array}$ & $\begin{array}{l}\text { Tekla Brettner } \\
\text { Maria Picha }\end{array}$ & $\begin{array}{l}10 \\
15\end{array}$ & $\begin{array}{l}\text { Szematyzm (...) 1843, } \\
\text { s. } 3,11\end{array}$ \\
\hline $1843 / 44$ & $\begin{array}{l}\text { Przemyśl } \\
\text { Rzeszów }\end{array}$ & $\begin{array}{l}\text { Tekla Brettner } \\
\text { Maria Picha }\end{array}$ & $\begin{array}{l}16 \\
17\end{array}$ & $\begin{array}{l}\text { Szematyzm (...) } 1844 \text {, } \\
\text { s. } 4,10\end{array}$ \\
\hline $1844 / 45$ & $\begin{array}{l}\text { Przemyśl } \\
\text { Rzeszów }\end{array}$ & $\begin{array}{l}\text { Tekla Brettner } \\
\text { Maria Picha }\end{array}$ & $\begin{array}{l}13 \\
12 \\
\end{array}$ & $\begin{array}{l}\text { Szematyzm (...) } 1845 \text {, } \\
\text { s. } 6,13\end{array}$ \\
\hline $1845 / 46$ & $\begin{array}{l}\text { Przemyśl } \\
\text { Rzeszów }\end{array}$ & $\begin{array}{l}\text { Tekla Brettner } \\
\text { Maria Picha }\end{array}$ & $\begin{array}{l}15 \\
17 \\
\end{array}$ & $\begin{array}{l}\text { Szematyzm (...) 1846, } \\
\text { s. } 6,14\end{array}$ \\
\hline $1846 / 47$ & $\begin{array}{l}\text { Przemyśl } \\
\text { Rzeszów }\end{array}$ & $\begin{array}{l}\text { Karolina Grzybowska } \\
\text { Tekla Brettner } \\
\text { Maria Picha } \\
\text { Karolina Krynicka }\end{array}$ & $\begin{array}{c}13 \\
16 \\
20 \\
9\end{array}$ & $\begin{array}{l}\text { Szematyzm (...) } 1847 \text {, } \\
\text { s. } 6,15\end{array}$ \\
\hline $1847 / 48$ & $\begin{array}{l}\text { Przemyśl } \\
\text { Sambor }\end{array}$ & $\begin{array}{l}\text { Karolina Grzybowska } \\
\text { Hermina Bychawska }\end{array}$ & $\begin{array}{r}14 \\
\text { b.d. }\end{array}$ & $\begin{array}{l}\text { Szematyzm (...) } 1848 \text {, } \\
\text { s. } 6,10\end{array}$ \\
\hline $1848 / 49$ & $\begin{array}{l}\text { Przemyśl } \\
\text { Sambor }\end{array}$ & $\begin{array}{l}\text { Maria Hild } \\
\text { Karolina Grzybowska } \\
\text { Hermina Bychawska }\end{array}$ & $\begin{array}{l}\text { b.d. } \\
21 \\
12\end{array}$ & $\begin{array}{l}\text { Szematyzm (...) } 1849 \text {, } \\
\text { s. } 6,10\end{array}$ \\
\hline $1849 / 50$ & $\begin{array}{l}\text { Przemyśl } \\
\text { Sambor }\end{array}$ & $\begin{array}{l}\text { Maria Hild } \\
\text { Karolina Grzybowska } \\
\text { Hermina Bychawska }\end{array}$ & $\begin{array}{c}11 \\
9 \\
15\end{array}$ & $\begin{array}{l}\text { Szematyzm (...) } 1850 \text {, } \\
\text { s. } 5-6,9\end{array}$ \\
\hline $1850 / 51$ & $\begin{array}{l}\text { Przemyśl } \\
\text { Sambor }\end{array}$ & $\begin{array}{l}\text { Maria Hild } \\
\text { Karolina Grzybowska } \\
\text { Hermina Bychawska }\end{array}$ & $\begin{array}{l}10 \\
11 \\
21\end{array}$ & $\begin{array}{l}\text { Szematyzm (...) } 1851 \text {, } \\
\text { s. } 5,9\end{array}$ \\
\hline $1851 / 52$ & $\begin{array}{l}\text { Przemyśl } \\
\text { Sambor }\end{array}$ & $\begin{array}{l}\text { Maria Hild } \\
\text { Karolina Grzybowska } \\
\text { Hermina Bychawska }\end{array}$ & $\begin{array}{c}10 \\
9 \\
19\end{array}$ & $\begin{array}{l}\text { Szematyzm (...) } 1852 \text {, } \\
\text { s. } 5,9\end{array}$ \\
\hline $1852 / 53$ & $\begin{array}{l}\text { Przemyśl } \\
\text { Sambor } \\
\text { Jasło }\end{array}$ & $\begin{array}{l}\text { Maria Hild } \\
\text { Karolina Grzybowska } \\
\text { Hermina Bychawska } \\
\text { Karolina Krynicka }\end{array}$ & $\begin{array}{c}12 \\
5 \\
22 \\
9\end{array}$ & $\begin{array}{l}\text { Szematyzm (...) } 1853 \text {, } \\
\text { s. } 5,9,19\end{array}$ \\
\hline $1853 / 54$ & Przemyśl & $\begin{array}{l}\text { Maria Hild } \\
\text { Karolina Grzybowska }\end{array}$ & $\begin{array}{l}12 \\
11\end{array}$ & $\begin{array}{l}\text { Szematyzm (...) 1854, } \\
\text { s. } 6,9,19\end{array}$ \\
\hline
\end{tabular}




\begin{tabular}{|c|c|c|c|c|}
\hline 1 & 2 & 3 & 4 & 5 \\
\hline $1853 / 54$ & $\begin{array}{l}\text { Sambor } \\
\text { Jasło }\end{array}$ & $\begin{array}{l}\text { Hermina Bychawska } \\
\text { Karolina Krynicka }\end{array}$ & $\begin{array}{l}16 \\
18\end{array}$ & $\begin{array}{l}\text { Szematyzm (..) } 1854 \text {, } \\
\text { s. } 6,9,19\end{array}$ \\
\hline $1854 / 55$ & $\begin{array}{l}\text { Przemyśl } \\
\text { Sambor } \\
\text { Jasło }\end{array}$ & $\begin{array}{l}\text { Maria Hild } \\
\text { Eleonora Jakobschütz } \\
\text { Karolina Grzybowska } \\
\text { Hermina Bychawska } \\
\text { Karolina Krynicka }\end{array}$ & $\begin{array}{c}12 \\
8 \\
15 \\
16 \\
18\end{array}$ & $\begin{array}{l}\text { Szematyzm (...) } 1855 \text {, } \\
\text { s. } 6,9,18\end{array}$ \\
\hline $1855 / 56$ & $\begin{array}{l}\text { Przemyśl } \\
\text { Sambor } \\
\text { Jasło }\end{array}$ & $\begin{array}{l}\text { Maria Hild } \\
\text { Eleonora Jakobschütz } \\
\text { Hermina Bychawska } \\
\text { Karolina Krynicka }\end{array}$ & $\begin{array}{r}14 \\
\text { b.d. } \\
16 \\
18\end{array}$ & $\begin{array}{l}\text { Szematyzm (...) } 1856 \text {, } \\
\text { s. } 5-6,8, \\
16\end{array}$ \\
\hline $1856 / 57$ & $\begin{array}{l}\text { Przemyśl } \\
\text { Sambor } \\
\text { Jasło }\end{array}$ & $\begin{array}{l}\text { Maria Hild } \\
\text { Hermina Bychawska } \\
\text { Kazimiera Zdrojkowska }\end{array}$ & $\begin{array}{l}\text { b.d. } \\
16 \\
20\end{array}$ & $\begin{array}{l}\text { Szematyzm (...) } 1857 \text {, } \\
\text { s. } 5,8,14\end{array}$ \\
\hline $1857 / 58$ & $\begin{array}{l}\text { Przemyśl } \\
\text { Sambor } \\
\text { Rzeszów } \\
\text { Jasło }\end{array}$ & $\begin{array}{l}\text { Maria Hild } \\
\text { Hermina Bychawska } \\
\text { Maria Magierowska } \\
\text { Kazimiera Zdrojkowska }\end{array}$ & $\begin{array}{r}18 \\
16 \\
\text { b.d. } \\
18\end{array}$ & $\begin{array}{l}\text { Szematyzm (...) } 1858 \text {, } \\
\text { s. } 5,8,11,15\end{array}$ \\
\hline $1858 / 59$ & $\begin{array}{l}\text { Przemyśl } \\
\text { Sambor } \\
\text { Rzeszów } \\
\text { Jasło }\end{array}$ & $\begin{array}{l}\text { Maria Hild } \\
\text { Hermina Bychawska } \\
\text { Maria Magierowska } \\
\text { Kazimiera Zdrojkowska }\end{array}$ & $\begin{array}{l}10 \\
16 \\
15 \\
22\end{array}$ & $\begin{array}{l}\text { Szematyzm (...) } 1859 \text {, } \\
\text { s. } 5,8,11,15\end{array}$ \\
\hline $1859 / 60$ & $\begin{array}{l}\text { Przemyśl } \\
\text { Sambor } \\
\text { Rzeszów } \\
\text { Jasło }\end{array}$ & $\begin{array}{l}\text { Maria Hild } \\
\text { Hermina Bychawska } \\
\text { Maria Magierowska } \\
\text { Kazimiera Zdrojkowska }\end{array}$ & $\begin{array}{l}20 \\
16 \\
12 \\
24\end{array}$ & $\begin{array}{l}\text { Szematyzm (...) } 1860 \text {, } \\
\text { s. } 5,8,12,16\end{array}$ \\
\hline $1860 / 61$ & $\begin{array}{l}\text { Przemyśl } \\
\text { Rzeszów } \\
\text { Przeworsk } \\
\text { Jasło }\end{array}$ & $\begin{array}{l}\text { Maria Hild } \\
\text { Maria Magierowska } \\
\text { Aniela Ostafińska } \\
\text { Kazimiera Zdrojkowska }\end{array}$ & $\begin{array}{c}34 \\
\text { b.d. } \\
7 \\
25\end{array}$ & $\begin{array}{l}\text { Szematyzm (...) 1861, } \\
\text { s. } 6,14,17,18\end{array}$ \\
\hline $1861 / 62$ & $\begin{array}{l}\text { Przemyśl } \\
\text { Rzeszów } \\
\text { Przeworsk }\end{array}$ & $\begin{array}{l}\text { Maria Hild } \\
\text { Adela Monseu } \\
\text { Maria Magierowska } \\
\text { Róża Herbst } \\
\text { Kazimiera Zdrojkowska } \\
\text { Aniela Ostafińska }\end{array}$ & $\begin{array}{r}16 \\
10 \\
\text { b.d. } \\
10 \\
\text { b.d. } \\
12\end{array}$ & $\begin{array}{l}\text { Szematyzm (...) } 1862 \text {, } \\
\text { s. } 6,14,15,18\end{array}$ \\
\hline $1862 / 63$ & Przemyśl & $\begin{array}{l}\text { Maria Hild } \\
\text { Adela Monseu }\end{array}$ & $\begin{array}{l}12 \\
10\end{array}$ & $\begin{array}{l}\text { Szematyzm (...) } 1863 \text {, } \\
\text { s. } 6,15,19\end{array}$ \\
\hline
\end{tabular}




\begin{tabular}{|c|c|c|c|c|}
\hline 1 & 2 & 3 & 4 & 5 \\
\hline $1862 / 63$ & $\begin{array}{l}\text { Rzeszów } \\
\text { Przeworsk }\end{array}$ & $\begin{array}{l}\text { Kazimiera Zdrojkowska } \\
\text { Róża Herbst } \\
\text { Aniela Ostafińska }\end{array}$ & $\begin{array}{l}22 \\
15 \\
12\end{array}$ & $\begin{array}{l}\text { Szematyzm (...) 1863, } \\
\text { s. } 6,15,19\end{array}$ \\
\hline $1863 / 64$ & $\begin{array}{l}\text { Przemyśl } \\
\text { Rzeszów } \\
\text { Przeworsk }\end{array}$ & $\begin{array}{l}\text { Maria Hild } \\
\text { Adela Monseu } \\
\text { Kazimiera Zdrojkowska } \\
\text { Róża Herbst } \\
\text { Aniela Ostafińska }\end{array}$ & $\begin{array}{l}22 \\
16 \\
31 \\
25 \\
10\end{array}$ & $\begin{array}{l}\text { Szematyzm (...) 1864, } \\
\text { s. } 6,17,21\end{array}$ \\
\hline $1864 / 65$ & $\begin{array}{l}\text { Przemyśl } \\
\text { Rzeszów } \\
\text { Przeworsk }\end{array}$ & $\begin{array}{l}\text { Maria Hild } \\
\text { Adela Monseu } \\
\text { Kazimiera Zdrojkowska } \\
\text { Róża Herbst } \\
\text { Józefa Grossmann } \\
\text { Aniela Ostafińska }\end{array}$ & $\begin{array}{c}15 \\
16 \\
30 \\
32 \\
9 \\
12\end{array}$ & $\begin{array}{l}\text { Szematyzm (...) } 1865 \text {, } \\
\text { s. } 6,18,22\end{array}$ \\
\hline $1865 / 66$ & $\begin{array}{l}\text { Przemyśl } \\
\text { Rzeszów } \\
\text { Przeworsk } \\
\text { Jasło }\end{array}$ & $\begin{array}{l}\text { Maria Hild } \\
\text { Adela Monseu } \\
\text { Kazimiera Zdrojkowska } \\
\text { Aniela Ostafińska } \\
\text { Julia Delattre }\end{array}$ & $\begin{array}{l}17 \\
16 \\
31 \\
22 \\
12\end{array}$ & $\begin{array}{l}\text { Szematyzm (...) } 1866 \text {, } \\
\text { s. } 6,7,18,23,29\end{array}$ \\
\hline $1866 / 67$ & $\begin{array}{l}\text { Przemyśl } \\
\text { Rzeszów } \\
\text { Leżajsk } \\
\text { Przeworsk }\end{array}$ & $\begin{array}{l}\text { Maria Hild } \\
\text { Adela Monseu } \\
\text { Kazimiera Zdrojkowska } \\
\text { Maria Richta } \\
\text { Teresa Nachtschein } \\
\text { Aniela Ostafińska }\end{array}$ & $\begin{array}{r}17 \\
16 \\
30 \\
12 \\
\text { b.d. } \\
22\end{array}$ & $\begin{array}{l}\text { Szematyzm (...) } 1867 \text {, } \\
\text { s. } 6,7,18,22,23\end{array}$ \\
\hline $1867 / 68$ & $\begin{array}{l}\text { Przemyśl } \\
\text { Rzeszów } \\
\text { Leżajsk }\end{array}$ & $\begin{array}{l}\text { Maria Hild } \\
\text { Adela Monseu } \\
\text { Kazimiera Zdrojkowska } \\
\text { Teresa Nachtschein }\end{array}$ & $\begin{array}{l}17 \\
\text { b.d. } \\
27 \\
\text { b.d. }\end{array}$ & $\begin{array}{l}\text { Szematyzm (...) } 1868 \text {, } \\
\text { s. } 6,7,18,22\end{array}$ \\
\hline
\end{tabular}

Źródło: Szematyzmy szkół ludowych diecezji przemyskiej obrz. łac. na lata 1842-1868, passim.

Analizując stan liczbowy omawianych zakładów, należy stwierdzić, że w diecezji przemyskiej w latach 1841-1868 łącznie otwarto ich 18. Stosowne informacje zamieszczono w tabeli 4. Najwięcej placówek było w Rzeszowie (7) i Przemyślu (5). W Jaśle utworzono 3, w Samborze, Przeworsku i Leżajsku - po 1. Najdłużej spośród nich działała szkoła M. Hild w Przemyślu (20 lat). Dość długą historię miał także zakład H. Bychawskiej w Samborze, który istniał 13 lat. Inne konwikty funkcjonowały znacznie krócej (poniżej 10 lat), z tego $6 \mathrm{w}$ przedziale od 1 roku do 2 lat. Warto też zwrócić uwagę na osobę K. Zdrojkowskiej, która najpierw (w latach 1856-1861) prowadziła konwikt w Jaśle, a w okresie 1861-1868 działała w Rzeszowie. 
Tabela 4. Okres istnienia prywatnych żeńskich zakładów edukacyjnych w miastach diecezji przemyskiej w latach 1841-1868

\begin{tabular}{|l|l|l|c|}
\hline \multicolumn{1}{|c|}{ Miasto } & \multicolumn{1}{|c|}{$\begin{array}{c}\text { Wlaścicielka zakładu } \\
\text { edukacyjnego }\end{array}$} & Lata szkolne & $\begin{array}{c}\text { Ogólem } \\
\text { lat }\end{array}$ \\
\hline \multirow{3}{*}{ Przemyśl } & Tekla Brettner & $1842 / 43-1846 / 47$ & 5 \\
& Karolina Grzybowska & $1846 / 47-1854 / 55$ & 9 \\
& Maria Hild & $1848 / 49-1867 / 68$ & 20 \\
& Eleonora Jakobschütz & $1854 / 55-1855 / 56$ & 2 \\
& Adela Monseu & $1861 / 62-1867 / 68$ & 7 \\
\hline \multirow{5}{*}{ Rzeszów } & Maria Picha & $1841 / 42-1846 / 47$ & 6 \\
& Karolina Krynicka & $1846 / 47$ & 1 \\
& Maria Magierowska & $1857 / 58-1861 / 62$ & 5 \\
& Róża Herbst & $1861 / 62-1864 / 65$ & 4 \\
& Kazimiera Zdrojkowska & $1861 / 62-1867 / 68$ & 1 \\
\hline Sambor & Józefa Grossmann & $1864 / 65$ & 1 \\
\hline \multirow{3}{*}{ Jasło } & Maria Richta & $1866 / 67$ & 13 \\
\hline Przeworsk & Hermina Bychawska & $1847 / 48-1859 / 60$ & 4 \\
\hline Leżajsk & Karolina Krynicka & $1852 / 53-1855 / 56$ & 5 \\
\hline & Kazimiera Zdrojkowska & $1865 / 66$ & 6 \\
\hline & Julia Delattre & $1860 / 61-1866 / 67$ & 2 \\
\hline
\end{tabular}

Źródło: Szematyzmy szkót ludowych diecezji przemyskiej obrz. łac. na lata 1842-1868, passim.

Także w przypadku panieńskich zakładów edukacyjnych działających na terenie diecezji tarnowskiej coroczne dane na ich temat znaleźć można jedynie w szematyzmach szkolnych. Należy jednak zauważyć, że czasami nie są one zbyt szczegółowe. Według tabeli 5 najstarsze informacje odnoszące się do analizowanych placówek z tego terenu pochodzą z roku szkolnego 1844/1845 i wymieniają dwa konwikty (K. Szymańskiej i K. Łazowskiej), obydwa w Tarnowie. W roku szkolnym 1849/1850 wspomniane źródło uwzględnia tylko ten drugi zakład. Identyczna sytuacja panowała w roku szkolnym 1852/1853. Później (w latach szkolnych 1854/1855 i 1855/1856) w szematyzmach podawano lakoniczne sumaryczne informacje zawierające jedynie ogólną liczbę pensji panieńskich, bez podania nazwisk ich właścicielek (w tym przypadku nadal chodziło wyłącznie o Tarnów). Mogę przypuszczać, iż ten jedyny zakład edukacyjny cały czas należał do K. Łazowskiej, która prowadziła go także w następnych latach. Natomiast dla okresu od 1857 do 1861 r. w szematyzmach brak jest jakichkolwiek informacji na ten temat. Może to wskazywać na czasowe zawieszenie pracy wspomnianej placówki lub pomijanie jej w wykazach szkół ludowych diecezji. Według tych źródeł 
dopiero w początkach lat 60 . XIX wieku konwikty zorganizowano także w innych miastach diecezji: Wieliczce, Podgórzu, Bochni i Dąbrowie Tarnowskiej.

Tabela 5. Prywatne zakłady kształcenia dziewcząt na terenie lacińskiej diecezji tarnowskiej w latach 1844-1870

\begin{tabular}{|c|c|c|c|}
\hline $\begin{array}{c}\text { Rok } \\
\text { szkolny }\end{array}$ & Miasto & Właścicielka zakładu & Źródlo \\
\hline 1 & 2 & 3 & 4 \\
\hline $1844 / 45$ & Tarnów & $\begin{array}{l}\text { Konstancja Szymańska } \\
\text { Konstancja Łazowska }\end{array}$ & $\begin{array}{l}\text { Szematyzm (...) } 1845 \text {, } \\
\text { s. } 5\end{array}$ \\
\hline $1847 / 48$ & Tarnów & $\begin{array}{l}\text { Konstancja Szymańska } \\
\text { Konstancja Łazowska }\end{array}$ & $\begin{array}{l}\text { Szematyzm (...) 1848, } \\
\text { s. } 5\end{array}$ \\
\hline $1849 / 50$ & Tarnów & Konstancja Łazowska & $\begin{array}{l}\text { Szematyzm (...) 1850, } \\
\text { s. } 9\end{array}$ \\
\hline $1851 / 52$ & Tarnów & Konstancja Łazowska & $\begin{array}{l}\text { Szematyzm (...) 1852, } \\
\text { s. } 9\end{array}$ \\
\hline $1852 / 53$ & Tarnów & Konstancja Łazowska & $\begin{array}{l}\text { Szematyzm (...) 1853, } \\
\text { s. } 9\end{array}$ \\
\hline $1854 / 55$ & Tarnów & b.d. & $\begin{array}{l}\text { Szematyzm (...) 1855, } \\
\text { s. } 53\end{array}$ \\
\hline $1855 / 56$ & Tarnów & b.d. & $\begin{array}{l}\text { Szematyzm (...) 1856, } \\
\text { s. } 53\end{array}$ \\
\hline $1861 / 62$ & $\begin{array}{l}\text { Tarnów } \\
\text { Wieliczka } \\
\text { Podgórze }\end{array}$ & $\begin{array}{l}\text { Konstancja Łazowska } \\
\text { Salomea Jordan } \\
\text { Karolina Żuk Skarszewska } \\
\text { Agnieszka Jałbrzykowska }\end{array}$ & $\begin{array}{l}\text { Szematyzm (...) 1862, s. } \\
10,45,48\end{array}$ \\
\hline $1862 / 63$ & $\begin{array}{l}\text { Tarnów } \\
\text { Podgórze }\end{array}$ & $\begin{array}{l}\text { Konstancja Łazowska } \\
\text { Salomea Jordan } \\
\text { Agnieszka Jałbrzykowska }\end{array}$ & $\begin{array}{l}\text { Szematyzm (...) 1863, s. } \\
10,50\end{array}$ \\
\hline $1863 / 64$ & $\begin{array}{l}\text { Tarnów } \\
\text { Wieliczka } \\
\text { Podgórze }\end{array}$ & $\begin{array}{l}\text { Paulina Łazowska } \\
\text { Aniela Stocka } \\
\text { Filomena Gutkowska } \\
\text { Agnieszka Jałbrzykowska }\end{array}$ & $\begin{array}{l}\text { Szematyzm (...) } 1864, \\
\text { s. } 73\end{array}$ \\
\hline $1864 / 65$ & $\begin{array}{l}\text { Tarnów } \\
\text { Wieliczka } \\
\text { Podgórze } \\
\text { Bochnia }\end{array}$ & $\begin{array}{l}\text { Paulina Łazowska } \\
\text { Aniela Stocka } \\
\text { Filomena Gutkowska } \\
\text { Agnieszka Jałbrzykowska } \\
\text { Salomea Jordan }\end{array}$ & $\begin{array}{l}\text { Szematyzm (...) 1865, } \\
\text { s. } 71\end{array}$ \\
\hline
\end{tabular}




\begin{tabular}{|c|c|c|c|}
\hline 1 & 2 & 3 & 4 \\
\hline $1865 / 66$ & $\begin{array}{l}\text { Tarnów } \\
\text { Wieliczka } \\
\text { Podgórze } \\
\text { Bochnia }\end{array}$ & $\begin{array}{l}\text { Paulina Łazowska } \\
\text { Aniela Stocka } \\
\text { Filomena Gutkowska } \\
\text { Agnieszka Jałbrzykowska } \\
\text { Salomea Jordan }\end{array}$ & $\begin{array}{l}\text { Szematyzm (...) 1866, } \\
\text { s. } 64\end{array}$ \\
\hline $1866 / 67$ & $\begin{array}{l}\text { Tarnów } \\
\text { Wieliczka } \\
\text { Podgórze } \\
\text { Bochnia }\end{array}$ & $\begin{array}{l}\text { Paulina Łazowska } \\
\text { Aniela Stocka } \\
\text { Filomena Gutkowska } \\
\text { Agnieszka Jałbrzykowska } \\
\text { Salomea Jordan }\end{array}$ & $\begin{array}{l}\text { Szematyzm (...) 1867, } \\
\text { s. } 53\end{array}$ \\
\hline $1867 / 68$ & $\begin{array}{l}\text { Tarnów } \\
\text { Podgórze }\end{array}$ & $\begin{array}{l}\text { Paulina Łazowska } \\
\text { N. [Teodora] Bryg } \\
\text { Agnieszka Jałbrzykowska }\end{array}$ & $\begin{array}{l}\text { Szematyzm (...) 1868, } \\
\text { s. } 55\end{array}$ \\
\hline $1868 / 69$ & $\begin{array}{l}\text { Tarnów } \\
\text { Dąbrowa Tarnowska } \\
\text { Podgórze }\end{array}$ & $\begin{array}{l}\text { Teodora Bryg } \\
\text { Maria Gołębiowska } \\
\text { Emilia Delattre } \\
\text { Julia Delattre } \\
\text { Olga Skrzeszewska } \\
\text { Agnieszka Jałbrzykowska }\end{array}$ & $\begin{array}{l}\text { Szematyzm (...) } 1869 \text {, } \\
\text { s. } 55\end{array}$ \\
\hline $1869 / 70$ & $\begin{array}{l}\text { Tarnów } \\
\text { Dąbrowa Tarnowska } \\
\text { Podgórze }\end{array}$ & $\begin{array}{l}\text { Teodora Bryg } \\
\text { Maria Gołębiowska } \\
\text { Emilia Delattre } \\
\text { Julia Delattre } \\
\text { Olga Skrzeszewska } \\
\text { Agnieszka Jałbrzykowska }\end{array}$ & $\begin{array}{l}\text { Szematyzm (...) } 1870 \text {, } \\
\text { s. } 59\end{array}$ \\
\hline
\end{tabular}

Źródło: Szematyzmy szkół ludowych $w$ diecezji tarnowskiej obrz. lac. na lata 1845-1870, passim.

Na obszarze diecezji tarnowskiej (tabela 6) łącznie działało 14 zakładów edukacyjnych dla dziewcząt, z czego aż 9 w Tarnowie. Pozostałe utworzono w Wieliczce (2), Podgórzu, Bochni i Dąbrowie Tarnowskiej (po 1). Większa część tych placówek działała bardzo krótko - od 1 do 3 lat, spora część od 4 do 5 lat. Dość długo (9 lat) istniał konwikt A. Jałbrzychowskiej w Podgórzu. Natomiast najdłużej działającą placówką była pensja K. Łazowskiej funkcjonująca w Tarnowie w okresie 1844-1863 r. (tj. 19 lat). Warto w tym miejscu zwrócić uwagę na osobę S. Jordan, która w latach 1861-1863 prowadziła zakład w Tarnowie, w latach 1864-1867 była zaś właścicielką konwiktu w Bochni. 
Tabela 6. Okres istnienia prywatnych żeńskich zakładów edukacyjnych w miastach diecezji tarnowskiej w latach 1844-1870

\begin{tabular}{|l|l|l|c|}
\hline \multicolumn{1}{|c|}{ Miasto } & \multicolumn{1}{|c|}{ Wlaścicielka zakladu } & \multicolumn{1}{|c|}{ Lata szkolne } & \multicolumn{1}{c|}{$\begin{array}{c}\text { Ogólem } \\
\text { lat }\end{array}$} \\
\hline \multirow{5}{*}{ Tarnów } & Konstancja Szymańska & $1844 / 45$ & 1 \\
& Konstancja Lazowska & $1844 / 45-1862 / 63$ & 19 \\
& Paulina Lazowska & $1863 / 64-1867 / 68$ & 5 \\
& Salomea Jordan & $1861 / 62-1862 / 63$ & 2 \\
& Aniela Stocka & $1863 / 64-1866 / 67$ & 4 \\
& Teodora Bryg & $1867 / 68-1869 / 70$ & 3 \\
\hline \multirow{3}{*}{ Tarnów } & Maria Gołębiowska & $1868 / 69-1869 / 70$ & 2 \\
& Emilia Delattre & $1868 / 69-1869 / 70$ & 2 \\
\hline \multirow{2}{*}{ Wieliczka } & Julia Delattre & $1868 / 69-1869 / 70$ & 2 \\
\hline Podgórze & Karolina Żuk Skarszewska & $1861 / 62$ & 1 \\
\hline Bochnia & Filomena Gutkowska & $1863 / 64-1866 / 67$ & 4 \\
\hline Dą̧browa Tarnowska & Agnieszka Jałbrzykowska & $1861 / 62-1869 / 70$ & 9 \\
\hline
\end{tabular}

Źródło: Szematyzmy szkót ludowych $w$ diecezji tarnowskiej obrz. tac. na lata 1845-1870, passim.

Dokonując zbiorczego zestawienia utworzonych w Galicji prywatnych zakładów kształcenia panien (tabela 7), należy stwierdzić, iż w okresie 1841-1870 uruchomiono 55 placówek. Najwięcej w diecezji lwowskiej - 23, z tym że tylko w trzech miastach. Z kolei najliczniejsza grupa miejscowości z omawianymi zakładami była w diecezji przemyskiej - 6. W Galicji najwięcej placówek zorganizowano we Lwowie (aż 18).

Tabela 7. Liczba prywatnych żeńskich zakładów kształcenia w Galicji w okresie od 1841 r. do 1870 r.

\begin{tabular}{|c|c|c|}
\hline Diecezja & Liczba zakładów & $\begin{array}{c}\text { Liczba miast } \\
\text { z zakladami }\end{array}$ \\
\hline Lwowska & 23 & 3 \\
\hline Przemyska & 18 & 6 \\
\hline Tarnowska & 14 & 13 \\
\hline Razem & 54 & 5 \\
\hline
\end{tabular}

Uwaga: w przypadku diecezji lwowskiej dane pochodzą wyłącznie z lat 60. XIX wieku, są więc niepełne.

Źródło: opracowanie własne. 
Jak wskazują dane zawarte w powyższych tabelach, najczęstszą formą zakładu kształcenia dziewcząt w Galicji były konwikty (pensje). Powszechnie tworzono je w miastach diecezji przemyskiej oraz tarnowskiej. Jedynie w archidiecezji lwowskiej, a konkretnie we Lwowie, oprócz nich organizowano także szkoły (tabela 1). Były to jednak przypadki rzadkie. We Lwowie w początkach lat 60 . XIX wieku właścicielką szkoły prywatnej bez internatu była A. Heindl. Szkoły bez zaplecza mieszkalnego w większej liczbie zaczęły powstawać $\mathrm{w}$ tym mieście dopiero od roku szkolnego 1865/1866. Prowadziły je wówczas: I. Ciesielska, A. Heindl i H. Pożakowska. W następnym roku szkolnym powstała kolejna placówka szkolna, której właścicielką została T. Śmiałowska. Tworzenie szkół bez zaplecza mieszkalnego mogło wynikać stąd, iż Lwów był dużym miastem i można było w nim znaleźć wolne stancje dla uczennic zamiejscowych. Ponadto zorganizowanie szkoły bez internatu, a następnie jej prowadzenie, było szybsze w realizacji i znacznie mniej kosztowne.

Większość placówek edukacyjnych zlokalizowano w miastach cyrkularnych (obwodowych): Lwów, Stanisławów, Kołomyja, Przemyśl, Rzeszów, Sambor, Tarnów i Bochnia. Reszta działała w siedzibach okręgów (dystryktów) oraz powiatów: Leżajsk, Przeworsk, Jasło, Dąbrowa Tarnowska i Wieliczka. Jedynie miasto Podgórze nie posiadało żadnego z wyżej wymienionych statusów administracyjnych. Było jednak wolnym, królewskim miastem leżącym w bliskim sąsiedztwie Krakowa. Najwięcej placówek funkcjonowało we Lwowie (w latach 60. XIX wie$\mathrm{ku}$ corocznie od 10 do 13). W innych miastach istniało ich równolegle znacznie mniej. Jedynie w Tarnowie w drugiej połowie lat 60 . XIX wieku corocznie działaky po 4 konwikty.

Zaprezentowane wyżej (w postaci tabel) dane statystyczne pozwalają także dokonać analizy sieci omawianych placówek edukacyjnych. Jednak (z powodu niekompletnych informacji) mogę to uczynić tylko w odniesieniu do ostatnich lat badanego okresu. I tak w roku szkolnym 1861/62 w Galicji funkcjonowały 23 zakłady. W następnych latach (do 1867 r.) ich liczba w zasadzie nie ulegała zmianie i oscylowała w przedziale 23-25 placówek. 


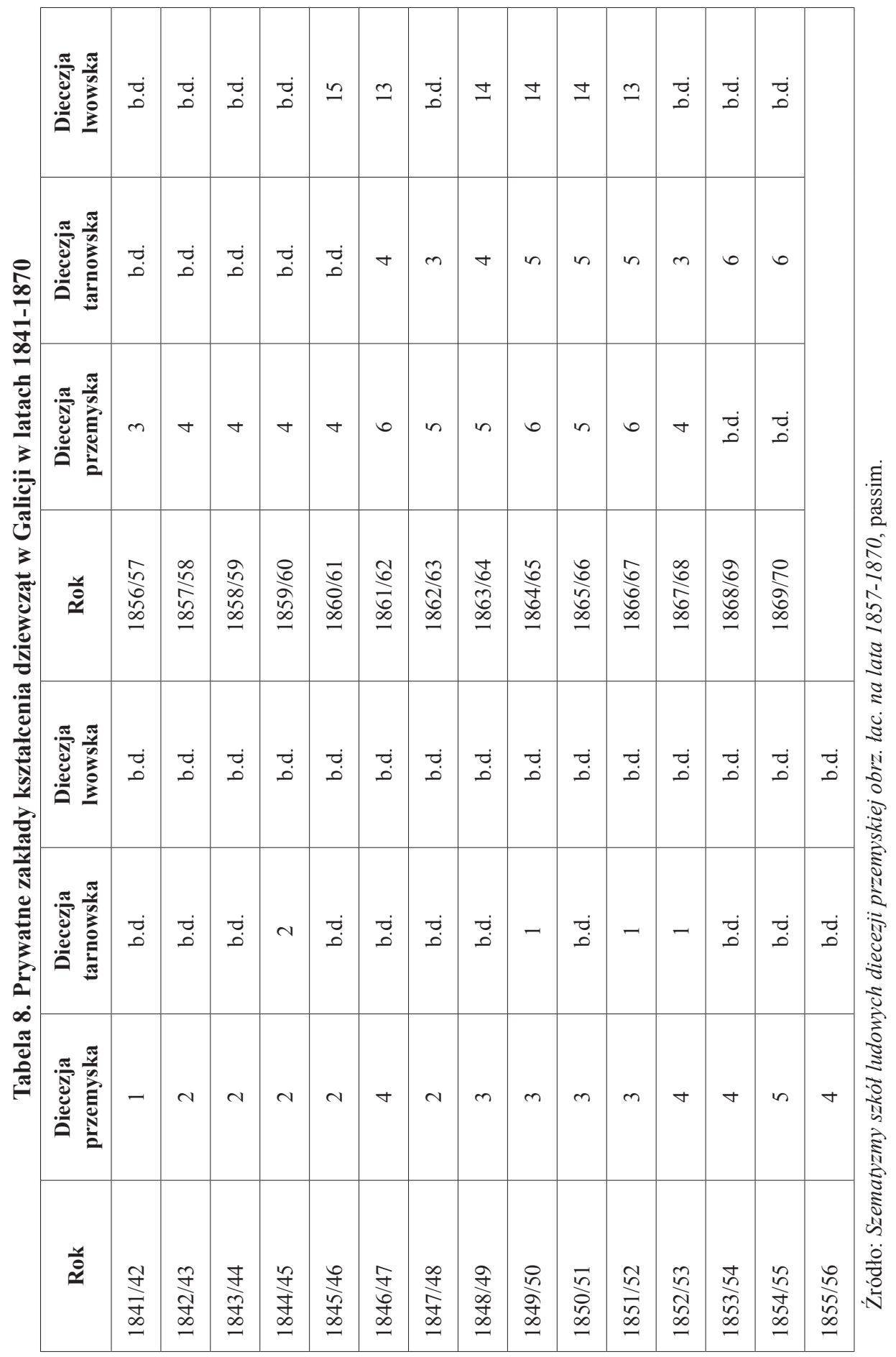


Dnia 6 maja 1816 r. władze państwowe przekazały nadzór nad wszystkimi typami szkół elementarnych poszczególnym konsystorzom biskupim łacińskim i unickim. Analizowane prywatne placówki edukacyjne dla dziewcząt odtąd zaczęły podlegać nadzorowi rzymskokatolickich władz diecezjalnych. Zakres kompetencji konsystorzy w tej kwestii określiło zarządzenie Gubernium z 18 kwietnia 1818 r. ${ }^{12} \mathrm{Na}$ jego mocy szkolnictwo zostało poddane nadzorowi zarówno państwowych władz obwodowych (cyrkularnych) i dystryktowych, jak i kościelnych władz diecezjalnych i dekanalnych ${ }^{13}$. Z ramienia konsystorzy biskupich funkcje diecezjalnych nadzorców szkół ludowych zazwyczaj sprawowali scholastycy katedralni. Średni szczebel nadzoru kościelnego stanowili nadzorcy okręgowi (dystryktowi), którymi zwykle zostawali miejscowi dziekani lub wicedziekani poszczególnych dekanatów pokrywających się terytorialnie z państwowymi okręgami szkolnymi. Do ich obowiązków należało regularne wizytowanie podległych szkół $\mathrm{z}$ terenu ich dekanatu ${ }^{14}$. Jedną z osób, która przez wiele lat bardzo aktywnie wykonywała swe obowiązki nadzorcze, był dziekan rzeszowski ks. Leopold Olcyngier, kontrolujący m.in. pracę szkół w Rzeszowie ${ }^{15}$. Tylko w łacińskiej archidiecezji lwowskiej wszystkie żeńskie konwikty i szkoły znajdujące się na terenie Lwowa podlegały kościelnemu nadzorcy I okręgu miejskiego i były jedynymi placówkami edukacyjnymi należącymi do tej jednostki administracyjnej. Nadzorcą okręgowym był każdorazowy proboszcz parafii św. Marcina. W roku szkolnym 1860/1861 funkcję tę pełnił ks. Michał Formaniosz ${ }^{16}$.

\section{Właścicielki zakładów kształcenia dziewcząt oraz kadra pedagogiczna}

Warto również przedstawić właścicielki konwiktów i szkół. W celu zapewnienia odpowiedniego poziomu nauczania i wychowania osoby chcące prowadzić pensje musiały poddać się egzaminowi przed właściwymi egzaminatorami i uzyskać zezwolenie władz państwowych na ich uruchomienie ${ }^{17}$. Analiza imion i nazwisk właścicielek tych zakładów pozwala wysnuć przypuszczenie, że większość

${ }^{12}$ F. Rzemieniuk, Unickie szkoły poczatkowe w Galicji w latach 1805-1914, „Rozprawy z Dziejów Oświaty", 33 (1990) s. 116.

${ }^{13}$ F. Persowski, Kartki z dziejów szkolnictwa w Galicji w I połowie XIX w. (głównie z terenu województwa rzeszowskiego), „Rocznik Naukowo-Dydaktyczny WSP w Rzeszowie”, z. 4: Nauki Pedagogiczne, (1967) s. 389.

${ }^{14}$ C. Majorek, W. Marmon, Oświata i kultura regionu tarnowskiego w okresie rozbiorów i niewoli, w: Tarnów. Dzieje miasta i regionu, t. 2: Czasy rozbiorów i Drugiej Rzeczypospolitej, red. F. Kiryk, Z. Ruta, Tarnów 1983, s. 269; D. Quirini-Popławska, Szkolnictwo krośnieńskie od XVII w. do 1914 r., w: Krosno. Studia z dziejów miasta i regionu, t. 2: 1918-1970, red. J. Garbacik, Kraków 1973, s. 343; Persowski, Kartki z dziejów, s. 389; Z. Felczyński, Rozwój kulturalny Przemyśla 17721918, w: Tysiac lat Przemyśla. Zarys historyczny, cz. 2, red. F. Persowski, A. Kunysz, J. Olszak, Warszawa-Kraków 1974, s. 156.

${ }^{15}$ J. Świeboda, Szkolnictwo ludowe w Rzeszowie pod zaborem austriackim (1772-1918), ,Rocznik Województwa Rzeszowskiego", 9 (1978) s. 6.

${ }^{16}$ Szematyzm szkót ludowych zostających pod nadzorem lwowskiego konsystorza metropolitalnego obrz. łac. na rok 1861, Lwów 1861, s. 9.

${ }^{17}$ Dormus, Włoch, Wojniak, Edukacja kobiet, s. 27. 
z nich była pochodzenia polskiego. Na 55 osób Polkami mogło być 30 kobiet $(54,5 \%)$, a $25(45,5 \%)$ cudzoziemkami, o francusko- i niemieckobrzmiących nazwiskach. Najwięcej właścicielek-cudzoziemek (11) prowadziło zakłady we Lwowie, czyli stolicy Galicji, mieście wielonarodowym i wielokulturowym. Przypuszczalnie część z kobiet organizujących te placówki należała do wieloletnich mieszkanek analizowanych miast. Wydaje się, że niektóre osiedlały się w nich specjalnie, z myślą o uruchomieniu placówek szkolno-wychowawczych dla panien $\mathrm{z}$ dobrze sytuowanych rodzin. 


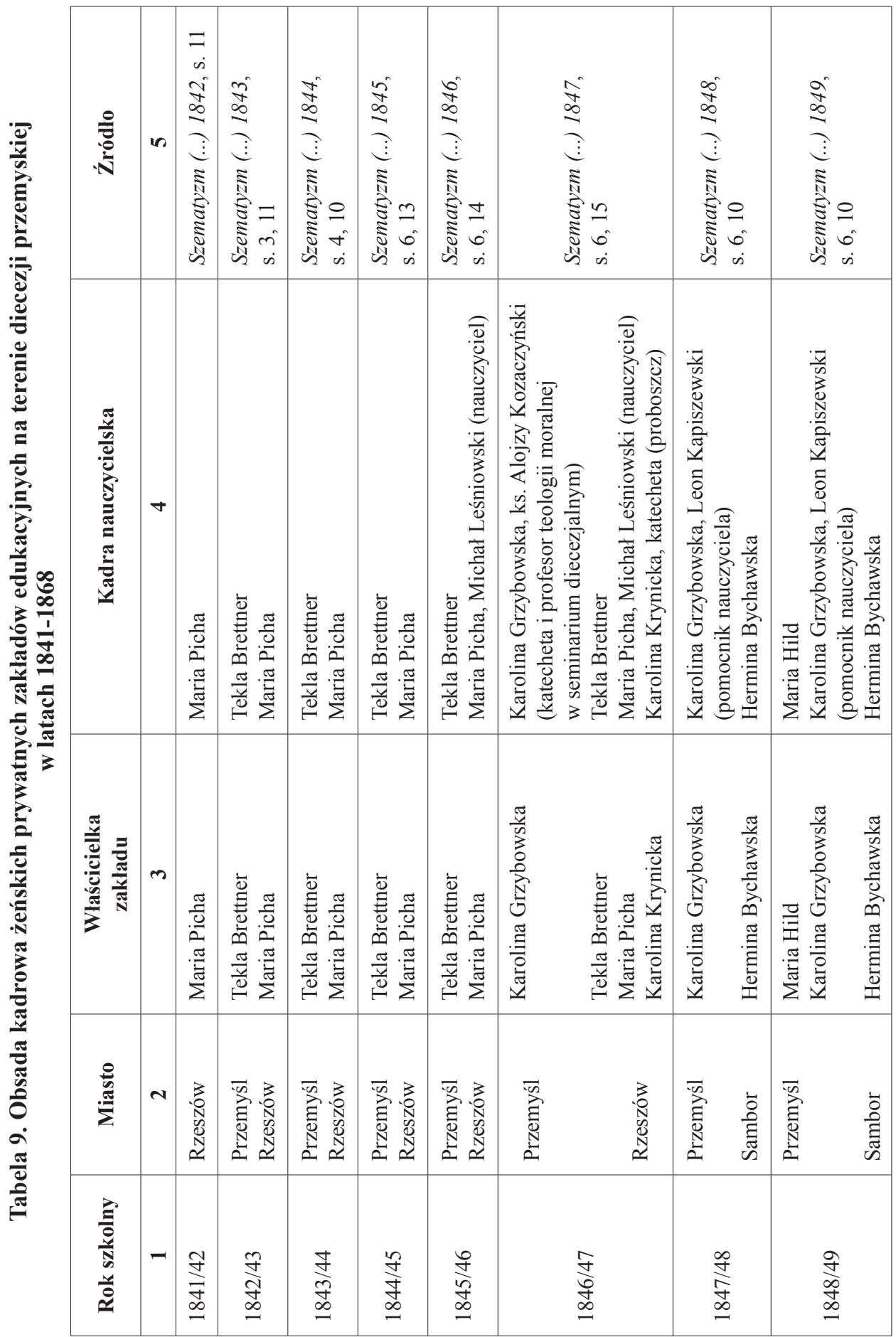




\begin{tabular}{|c|c|c|c|c|c|c|}
\hline in & 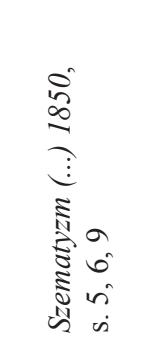 & 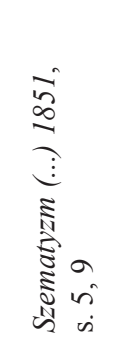 & 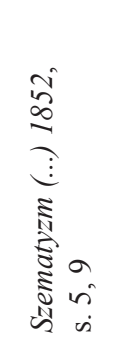 & 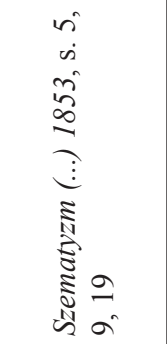 & 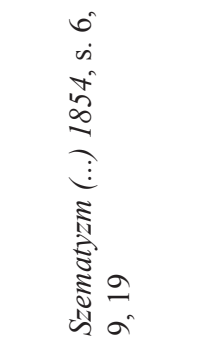 & 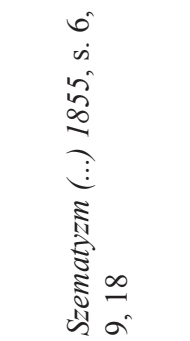 \\
\hline$\nabla$ & 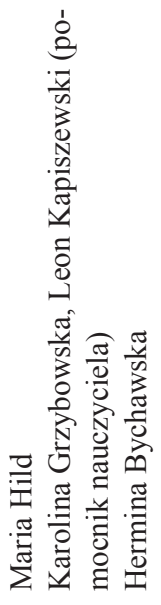 & 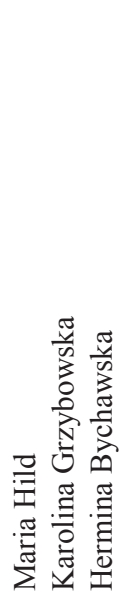 & 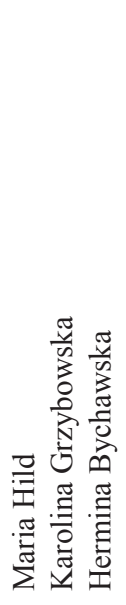 & 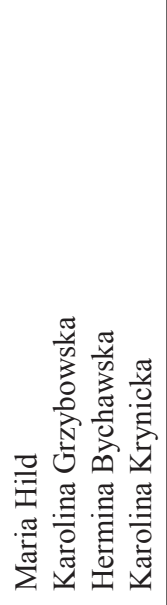 & 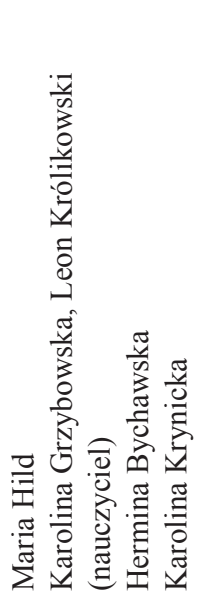 & 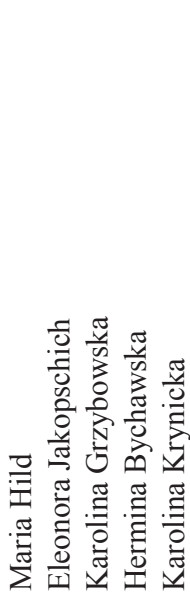 \\
\hline$m$ & 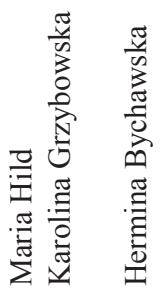 & 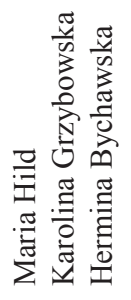 & 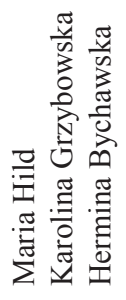 & 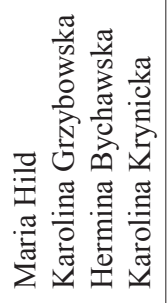 & 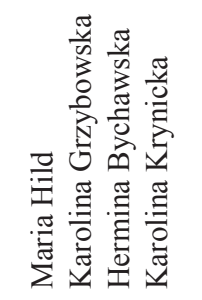 & 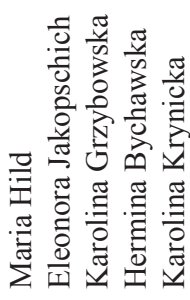 \\
\hline$N$ & 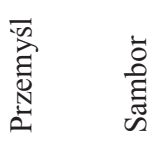 & 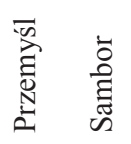 & 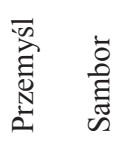 & 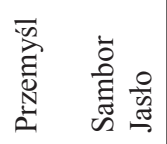 & 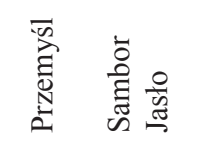 & 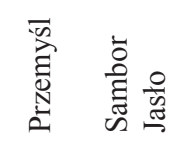 \\
\hline- & 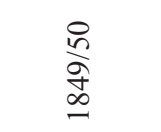 & $\begin{array}{l}\bar{n} \\
\infty \\
\infty \\
\infty\end{array}$ & $\frac{\tilde{n}}{\frac{\tilde{n}}{\infty}}$ & $\begin{array}{l}\tilde{n} \\
\underset{\sim}{\infty} \\
\infty\end{array}$ & $\begin{array}{l}\stackrel{+}{\infty} \\
\tilde{\infty} \\
\triangleq\end{array}$ & 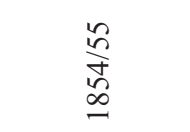 \\
\hline
\end{tabular}




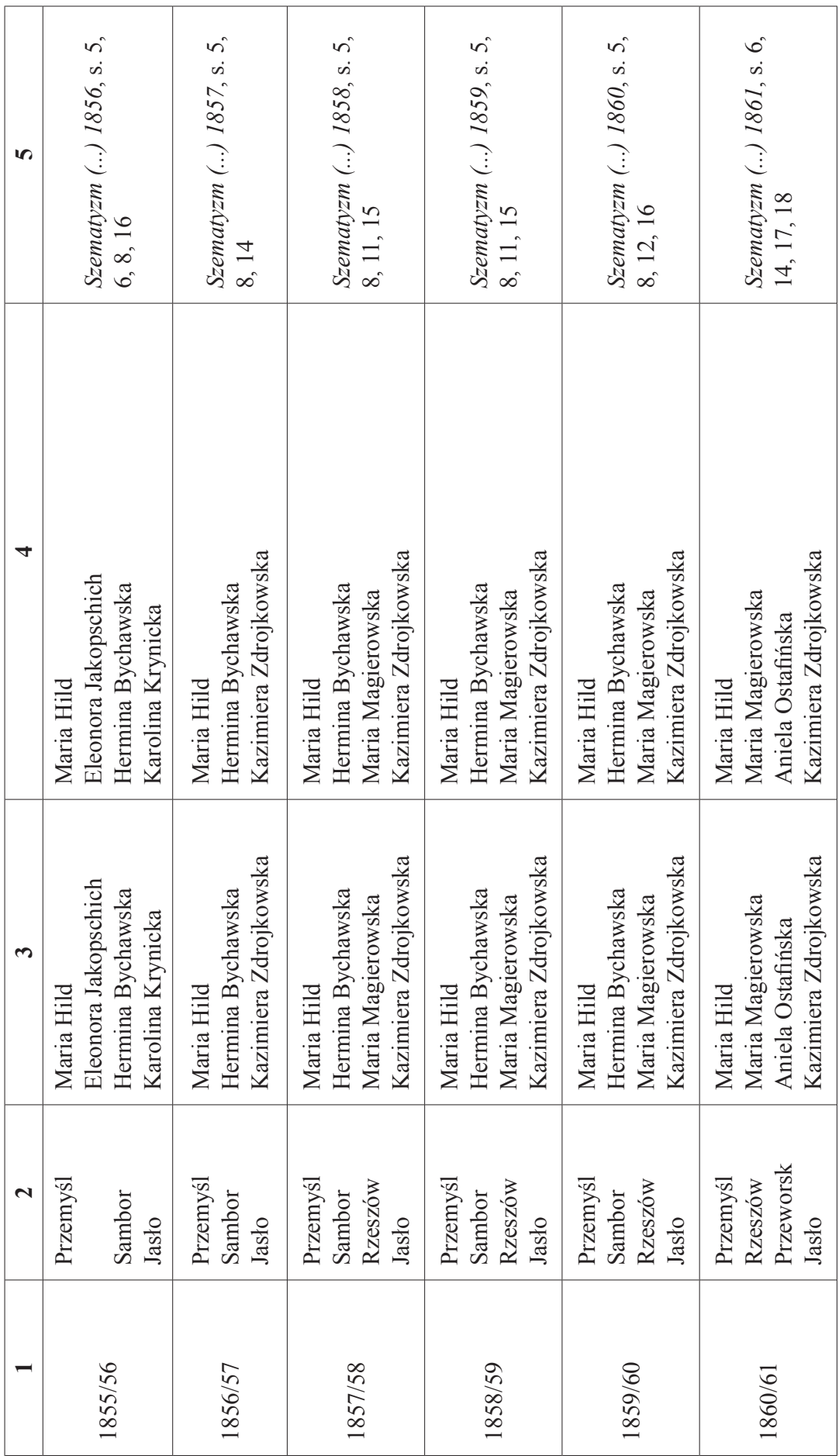




\begin{tabular}{|c|c|c|c|c|c|c|c|c|c|c|c|c|c|c|}
\hline in & \multicolumn{4}{|c|}{ 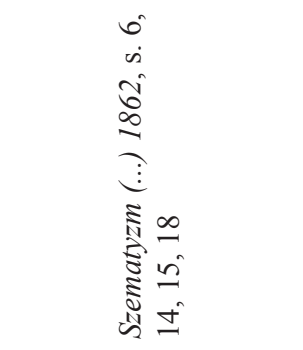 } & \multicolumn{5}{|c|}{ 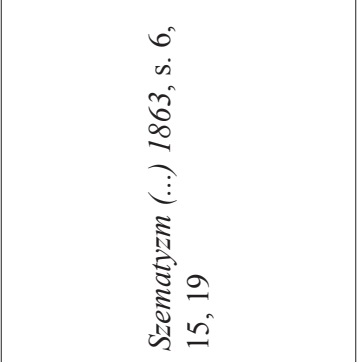 } & \multicolumn{2}{|c|}{ 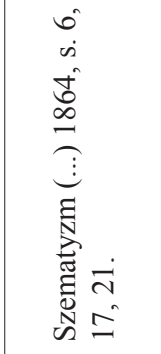 } & \multicolumn{3}{|c|}{ 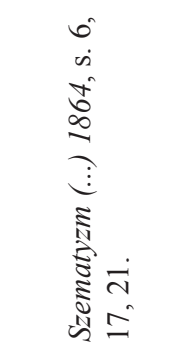 } \\
\hline$\nabla$ & 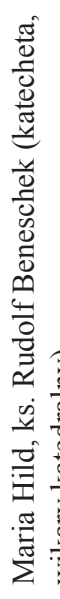 & 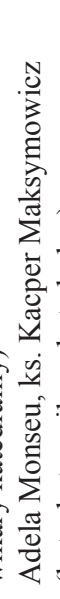 & 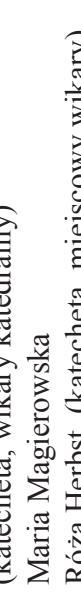 & 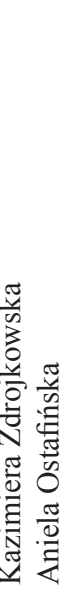 & 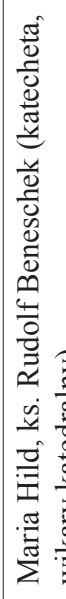 & 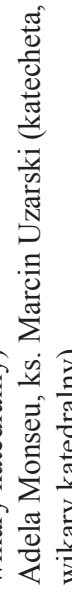 & 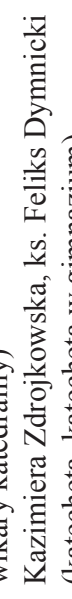 & 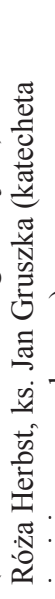 & 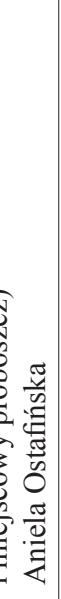 & 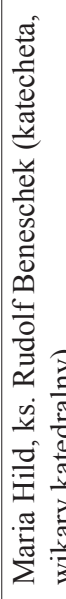 & 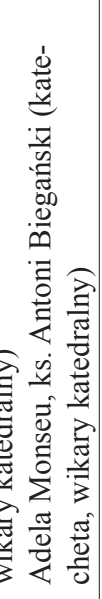 & 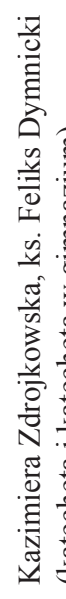 & 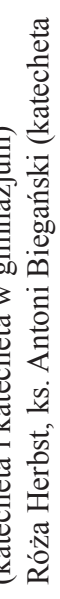 & 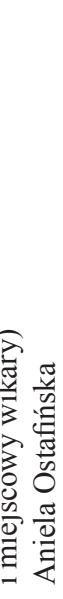 \\
\hline$m$ & 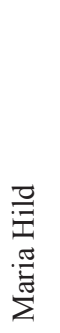 & $\begin{array}{l}\overrightarrow{\vec{J}} \\
\overline{0} \\
\sum_{0}^{0} \\
\frac{\pi}{0} \\
\frac{0}{2}\end{array}$ & 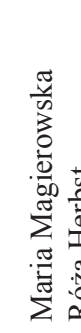 & 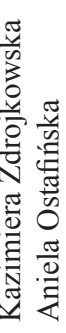 & 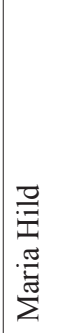 & $\begin{array}{l}\overrightarrow{0} \\
0 \\
0 \\
\sum_{0}^{0} \\
\frac{\pi}{0} \\
\frac{\pi}{2}\end{array}$ & 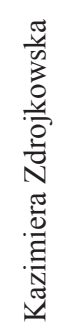 & 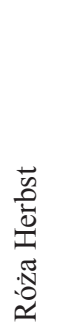 & 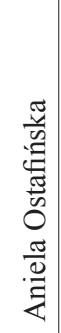 & 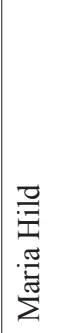 & $\begin{array}{l}\vec{\nabla} \\
0 \\
\sum_{0}^{0} \\
\frac{\pi}{0} \\
\frac{\pi}{2}\end{array}$ & 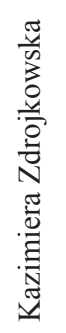 & 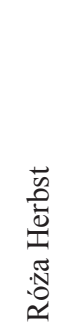 & 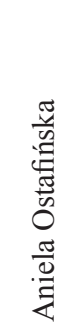 \\
\hline$N$ & 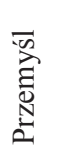 & & 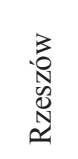 & 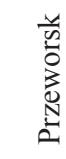 & 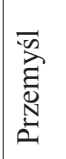 & & 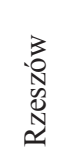 & & 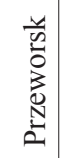 & & 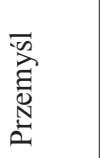 & 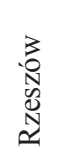 & & 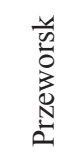 \\
\hline- & & & $\begin{array}{l}\text { రె } \\
\underset{0}{0} \\
\infty\end{array}$ & & & & $\begin{array}{l}\text { శె } \\
\text { ర్ } \\
\infty\end{array}$ & & & & $\begin{array}{l}\frac{J}{3} \\
\widehat{\infty} \\
\infty\end{array}$ & & $\begin{array}{l}\mathbb{0} \\
\text { Ob } \\
\infty\end{array}$ & \\
\hline
\end{tabular}




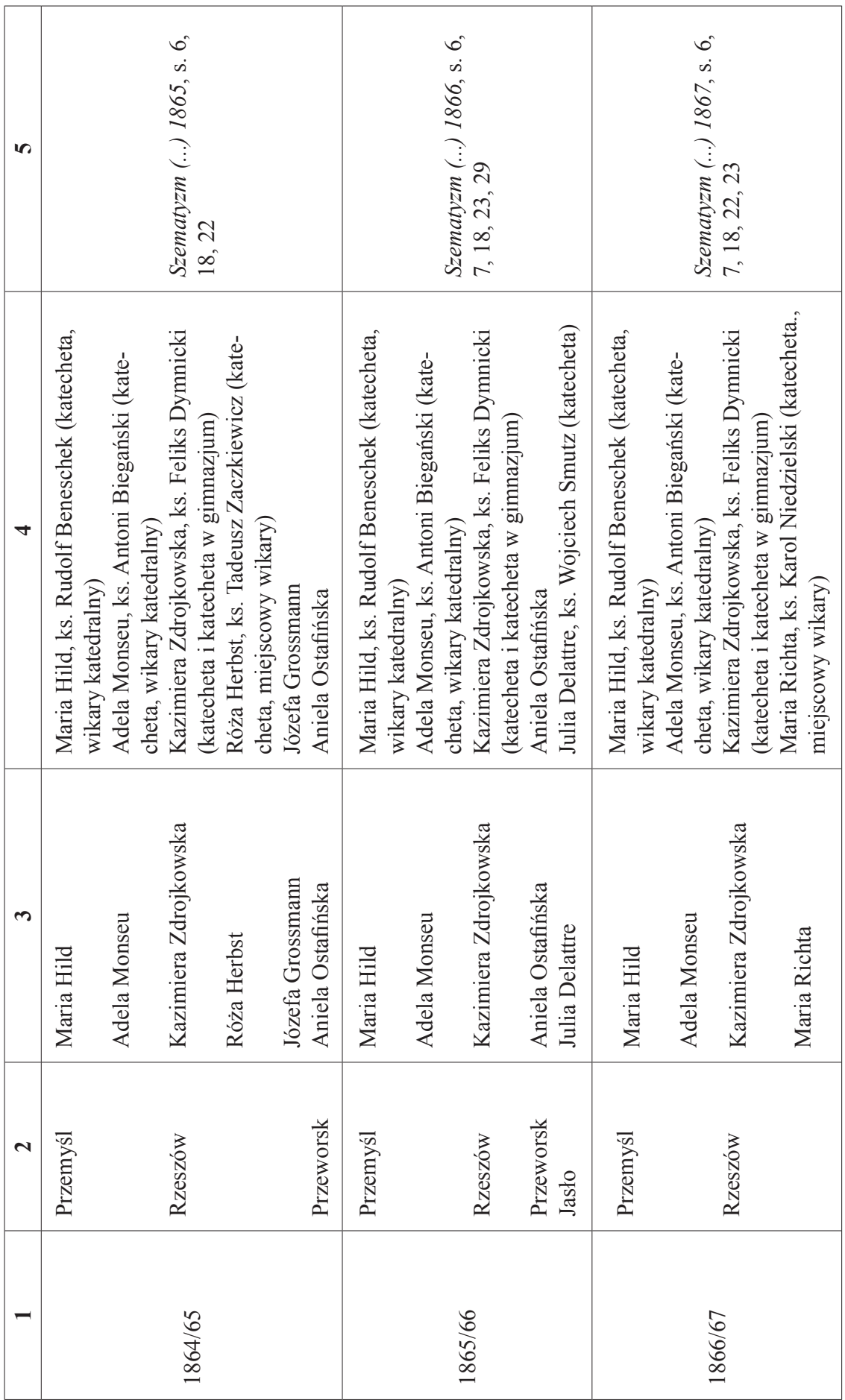




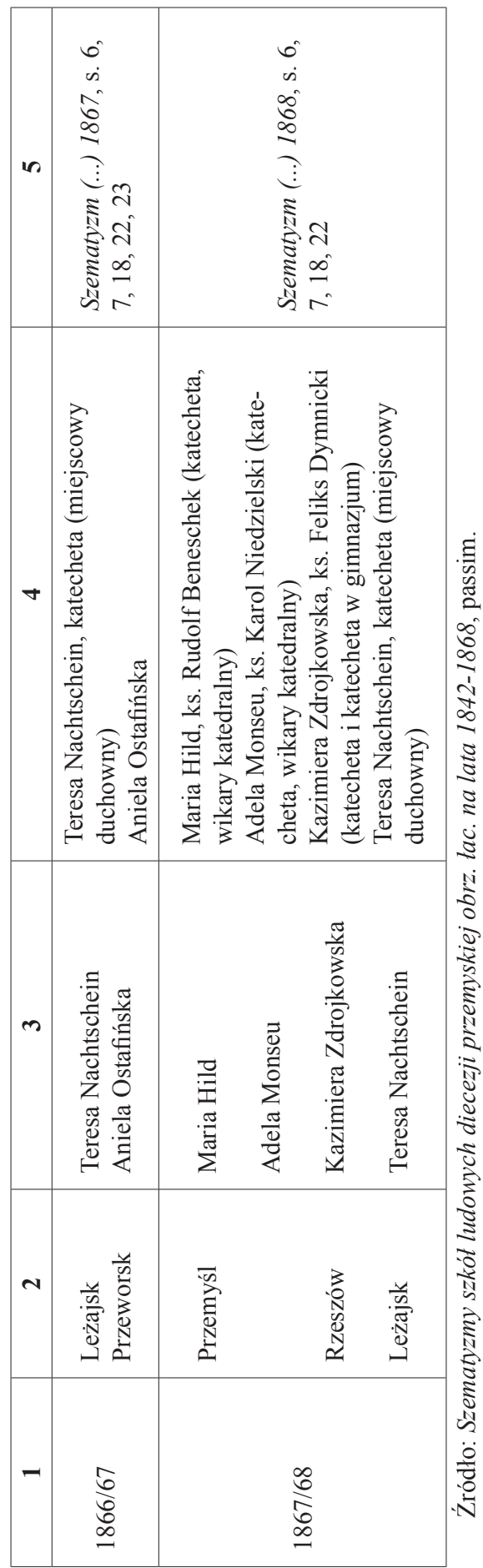


Wydaje się, że najbardziej znaną w Galicji właścicielką konwiktu panieńskiego była w tym okresie Felicja z Wasilewskich Boberska (1825-1889), która w 1853 r. otworzyła we Lwowie tego typu placówkę, kształcącą dziewczęta przez niemal trzydzieści lat. Dzięki jej staraniom dwa lata po rozpoczęciu funkcjonowania zakład uzyskał tzw. zatwierdzenie rządowe i cieszył się dużym uznaniem w środowisku lwowskim. Także sama inicjatorka przedsięwzięcia stała się czołową postacią w kulturze Lwowa. We wspomnieniach tych, którzy mieli możliwość zetknąć się z Felicją z Wasilewskich, dominują takie określenia na jej temat jak: „,równowaga ducha”, „niewymuszona skromność”, ,dobro”, „,naturalność w kontaktach z ludźmi”. Nie dziwi więc fakt, że lgnęły do niej uczennice lwowskiej pensji. Wychowanki F. Boberskiej odnosiły się do niej z szacunkiem i przywiązaniem, a jej pensja była miejscem, gdzie pracowano nad podnoszeniem poziomu moralnego i umysłowego kobiet lwowskich. Nie bez znaczenia była także propagowana przez nią idea krzewienia uczuć patriotycznych. Przykładem tych starań może być jej zaangażowanie w powstanie tajnego związku Klaudynek, którego członkinie ślubowały oddanie ojczyźnie. Jego celem było rozbudzanie i podnoszenie ducha narodowego wśród ludu wiejskiego. Posiadał swój statut oraz własną modlitwę za ojczyznę. Stowarzyszenie, wkrótce dość rozgałęzione, stało się w 1863 r. zawiązkiem organizacji niewieściej w Galicji, zasłużonej dla sprawy powstania styczniowego. Jego wybuch spowodował wyłonienie się z tej organizacji Komitetu Niewiast Polskich pod przewodnictwem F. Boberskiej, którą wkrótce aresztowano, a następnie w 1864 r. odebrano jej prawo edukowania, a zakład zamknięto ${ }^{18}$. Ponownie (za zgodą władz państwowych) udało się go otworzyć jesienią 1867 r. ${ }^{19}$ Zasługą Felicji z Wasilewskich była też atmosfera zakładu. Sama właścicielka, jako jego przełożona, potrafiła docenić sumienną i rzetelną pracę zarówno wychowanek, jak i zatrudnionych nauczycielek, które zawsze mogły liczyć na jej wyrozumiałość i wsparcie. Mówiąc o niej i jej działalności w służbie edukacji kobiet, można zauważyć, że zdecydowanie walczyła z kastowością szlachecką. Toteż uczennice zakładu rekrutowały się z różnych warstw społecznych, nie tylko z rodzin ziemiańskich, ale także mieszczańskich. Wszystkim starała się wpoić idee prawdziwie chrześcijańskiej demokracji, które sama wyniosła z domu rodzinnego. Jej wychowanki, obeznane z literaturą i historią Polski, pragnęły dla siebie większego udziału w życiu społecznym, współdziałania na równi z mężczyznami na polu wychowania narodowego czy innych sfer, a nie tylko pełnienia ról gospodyni, żony i matki. Przez wiele lat F. Boberska organizowała wykłady, których audytorium stanowiły zarówno byłe uczennice, jak i inne zainteresowane tematyką kobiety ${ }^{20}$.

Właścicielki pensji i szkół były równocześnie ich dyrektorkami oraz nauczycielkami. Przykładu dostarczają zakłady z terenu diecezji przemyskiej (tabela 9). Na jej podstawie można wysnuć wniosek, że dyrektorki rzadko zatrudniały dodatkowe osoby do prowadzenia nauki. Tylko w niektórych placówkach (M. Pichy w Rze-

18 J. Falkowska, W stużbie edukacji kobiet. Działalność Felicji Boberskiej z Wasilewskich (1825-1889), „Studia Paedagogica Ignatiana”, 19 (2016) nr 3, s. 128-129.

${ }^{19}$ Z. R., Felicya z Wasilewskich Boberska. Życiorys, Lwów 1893, s. 21.

${ }^{20}$ Tamże, s. 131-132. 
szowie i K. Grzybowskiej w Przemyślu) angażowano innych nauczycieli lub pomocników nauczycieli. Byli nimi wyłącznie mężczyźni - w pierwszej placówce M. Leśniowski (nauczyciel), w drugiej zaś L. Kapiszewski (pomocnik nauczyciela) i L. Królikowski (nauczyciel). Pracowali oni jednak krótko: M. Leśniowski dwa lata, L. Kapiszewski trzy lata, L. Królikowski rok.

Natomiast powszechne uzupełnienie kadry nauczycielskiej stanowili katecheci nauczający religii. Ich obecność $\mathrm{w}$ omawianych placówkach można prześledzić w oparciu o dane dla zakładów edukacyjnych z terenu diecezji przemyskiej. Wykazy imienne duchownych uczących w tamtejszych konwiktach pochodzą z lat 1861-1868. Obecność katechetów widoczna była we wszystkich placówkach, z wyjątkiem konwiktu A. Ostafińskiej, działającego w Przeworsku, oraz J. Grossmann z Rzeszowa. W przypadku tego drugiego wynikało to $\mathrm{z}$ faktu, iż gromadził on panny z rodzin żydowskich. W Przemyślu do prowadzenia tych zajęć zatrudniano wikarych z katedry. W pozostałych miastach byli to wikarzy z miejscowych kościołów parafialnych. Warto w tym miejscu wymienić ks. R. Benescheka pracującego w Przemyślu w konwikcie M. Hild, który był wykazywany w całym wyżej wymienionym okresie. W gronie katechetów nauczających w analizowanych placówkach w diecezji przemyskiej (tabela 9) znalazł się także ks. F. Dymnicki, pracujący w Rzeszowie w konwikcie K. Zdrojkowskiej (w latach od 1862 do co najmniej 1868 r.). Warto przybliżyć jego sylwetkę ze względu na rolę, jaką odegrał w historii Rzeszowa. F. Dymnicki urodził się 13 stycznia 1824 r. we Frysztaku, w niezbyt zamożnej rodzinie mieszczańskiej. Ukończył rzeszowskie gimnazjum. W 1845 r. (lub 1846 r.) wstąpił do Seminarium Duchownego w Przemyślu. Jednakże z uwagi na działalność patriotyczną w okresie Wiosny Ludów został z niego wydalony i święcenia otrzymał dopiero w $1851 \mathrm{r}$. W $1855 \mathrm{r}$. dostał nominację na zastępcę katechety gimnazjum w Rzeszowie. Po dwóch latach został katechetą w tej szkole. Powierzone mu obowiązki pełnił ponad dwadzieścia lat, aż do swej śmierci w 1876 r. Był przede wszystkim wychowawcą i duszpasterzem młodzieży gimnazjalnej. $Z$ tego względu jego najważniejszym obowiązkiem było nauczanie religii. Wywiązywał się z niego znakomicie, gdyż był dobrym, przygotowanym do pracy, kompetentnym, zatroskanym o losy wychowanków oraz wymagającym pedagogiem. W zakres jego obowiązków katechetycznych wchodziło ponadto: odprawianie wychowankom w każdą niedzielę mszy św. z egzortą, urządzanie nabożeństw szkolnych, organizowanie rekolekcji oraz wspólnej spowiedzi i komunii św. Należy zauważyć, iż w swoim duszpasterstwie oparł się głównie na dwóch nurtach pobożności: eucharystycznym i maryjnym, które z powodzeniem starał się zaszczepić swoim wychowankom. Owocowały one później w życiu wielu z nich. Badacz oświaty rzeszowskiej oraz galicyjskiej J. Świeboda nazywał go „najszlachetniejszym pedagogiem, przypuszczalnie w całej Galicji”"21. Reszta duchownych uwzględnionych $\mathrm{w}$ tabeli 9 podejmowała obowiązki katechetów na

${ }^{21}$ J. Świeboda, Dzieje I Gimnazjum w Rzeszowie 1786-1918, Rzeszów 1984, s. 84; 106, T. Ochenduszko, Dymnicki Feliks (1824-1876), w: Słownik biograficzny twórców oświaty $i$ kultury XIX i XX wieku Polski południowo-wschodniej, red. A. Meissner, K. Szmyd, Rzeszów 2011, s. 103-104; A. Motyka, Dymnicki Feliks (1824-1876), w: Diecezja Rzeszowska, www2.diecezja.rzeszow.pl/?q=node/1914 (dostęp: 10.04.2020). 
krótko, a ponadto niektórzy uczyli w różnych miastach w związku z przenoszeniem ich na nowe placówki parafialne: ks. A. Biegański (Rzeszów, Przemyśl) i ks. K. Niedzielski (Rzeszów, Przemyśl).

W diecezji lwowskiej we Lwowie katechetami byli wyłącznie księża rzymskokatoliccy pracujący w miejscowych parafiach (najczęściej wikarzy katedralni). Uczyli także proboszczowie niektórych parafii z terenu miasta oraz dominikanie. W konwikcie E. Cieleskiej katechizował ks. J. Aksentowicz, wikary z katedry ormiańskiej. Ponadto część katechetów dodatkowo pracowała w wyżej zorganizowanych szkołach lwowskich. Dla przykładu w roku szkolnym 1860/1861 w konwiktach B. Lauer i R. Lauer uczył ks. E. Willomitzer, katecheta w gimnazjum, a w konwikcie H. Bachotte - ks. K. Pielecki - katecheta w szkole realnej. Dobrą obsadę duszpasterską posiadały konwikty lwowskie w roku szkolnym 1863/1864, gdyż wśród katechetów byli księża z miejscowego seminarium duchownego, katedry oraz zakonnicy (dominikanin i franciszkanin) ${ }^{22}$. Wyjątkiem wśród duchownych prowadzących lekcje religii w tych zakładach był wspomniany wcześniej ks. J. Aksentowicz (uczący od początku lat 60. XIX wieku w szkole E. Cieleskiej). Był to jedyny kapłan ormiańskokatolicki zatrudniony w tych placówkach. W roku szkolnym 1866/1867 pracował on równocześnie jako katecheta w szkole głównej dla dziewcząt prowadzonej we Lwowie przez benedyktynki obrządku ormiańskokatolickiego ${ }^{23}$.

We Lwowie katecheci zazwyczaj prowadzili katechizację w większej grupie konwiktów. Przykładu dostarczają dane za rok szkolny 1860/1861. I tak ks. A. Hauptmann pracował równocześnie u A. Heindl, E. Neugebauer i E. Schürrer. Z kolei u B. Lauer i R. Lauer uczył ks. E. Willomitzer, w konwiktach E. Titz i F. Wasilewskiej zaś ks. J. Hausmann. W pensji H. Bachotte pracował ks. K. (Wenanty) Pielecki, który uczył religii także u B. Wierzbięty. Jedynie w 4 przypadkach (na 13) katecheci zatrudnieni byli tylko w 1 zakładzie $^{24}$. W konwiktach we Lwowie część katechetów często się zmieniała. Jednak większość pracowała w jednej placówce przez dłuższy czas. Z kolei obsada księży katechetów w konwiktach w Stanisławowie była płynna. W roku szkolnym 1860/1861 w dwóch pensjach zajęcia z religii realizowali miejscowi księża rzymskokatoliccy ${ }^{25}$. Natomiast w roku szkolnym 1861/1862 w konwikcie F. Nowakowskiej katechizował kapłan ormiańskokatolicki I. Isakowicz ${ }^{26}$.

\section{Wychowanki i uczennice}

W omawianych zakładach zdecydowanie dominowały dziewczęta pochodzące z rodzin ziemiańskich. Natomiast córki mieszczan miały możliwość pobierania

${ }^{22}$ Szematyzm szkół ludowych zostajacych pod nadzorem lwowskiego konsystorza metropolitalnego obrz. łac. na rok 1864, Lwów 1864, s. 9-10.

${ }^{23}$ Szematyzm szkót ludowych zostających pod nadzorem lwowskiego konsystorza metropolitalnego obrz. łac. na rok 1867, Lwów 1867, s. 5, 10.

${ }^{24}$ Szematyzm szkót ludowych 1861, s. 9.

${ }^{25}$ Tamże, s. 26.

${ }^{26}$ Szematyzm szkół ludowych zostajacych pod nadzorem lwowskiego konsystorza metropolitalnego obrz. łac. na rok 1862, Lwów 1862, s. 31. 
nauki w szkołach ogólnodostępnych. Warto bowiem zauważyć, że analizowane placówki edukacyjne na terenie wymienionych miast funkcjonowały równolegle z różnymi typami szkół ludowych (parafialnych, trywialnych i głównych). Niektóre z nich przeznaczone były wyłącznie dla dziewczą ${ }^{27}$. Należy jednak przypuszczać, że przedstawiciele stanu szlacheckiego woleli (ze względów prestiżowych) umieszczać swe córki w zakładach prywatnych. Na terenie Galicji prywatne zakłady edukacyjne tworzono z myślą o dziewczętach z rodzin rzymskokatolickich. Wyjątkiem był konwikt założony w Rzeszowie w roku szkolnym 1864/1865 przez J. Grossmann, w którym zaczęto edukować dziewczęta żydowskie. W pierwszym roku istnienia kształciło się w nim 9 Żydówek. Jednak (według szematyzmów szkół ludowych diecezji przemyskiej) działał on zaledwie rok $^{28}$. O dalszych losach tego konwiktu bowiem późniejsze źródła tego typu nie wspominają.

W myśl ówczesnych praktyk stosowanych we wszystkich zaborach (a więc i w Galicji) na naukę i mieszkanie przyjmowano stosunkowo nieduże grupy dziewcząt. Powodów mogło być kilka: ograniczone możliwości lokalowe i mieszkaniowe pensji oraz szkół, pojedyncze nauczycielki, które nie były w stanie pracować z większymi grupami dziewcząt oraz ich nadzorować. Posiłkując się danymi dla zakładów z terenu diecezji przemyskiej i tarnowskiej (tabela 10 i 11), można stwierdzić, że jednorazowo liczba uczennic w poszczególnych placówkach wahała się od kilku do ponad trzydziestu. Wśród zakładów były takie, które corocznie przyjmowały większą liczbę uczennic. Prym wiódł konwikt K. Zdrojkowskiej z Rzeszowa, który edukował $\mathrm{w}$ ciągu roku od 22 do 31 dziewcząt. Jak wynika z przytoczonych danych, liczba uczennic w jednym zakładzie co roku znacznie się zmieniała. Przykładu dostarcza konwikt M. Pichy z Rzeszowa, w którym w okresie lat 1841-1847 liczba wychowanek wahała się od 12 do 20. Jeszcze większe różnice występowały w pensji K. Grzybowskiej z Przemyśla, gdzie w latach 1846-1855 corocznie edukowało się od 5 do 21 panien. Z kolei w konwikcie K. Łazowskiej w Tarnowie w latach 1844-1853 liczba uczennic mieściła się w przedziale 5-24 (tabela 11).

Tabela 10. Liczba uczennic w prywatnych zakładach kształcenia dziewcząt na terenie diecezji przemyskiej w latach 1841-1868

\begin{tabular}{|c|c|c|c|}
\hline $\begin{array}{c}\text { Rok } \\
\text { szkolny }\end{array}$ & Liczba zakładów & $\begin{array}{c}\text { Liczba } \\
\text { uczennic }\end{array}$ & $\begin{array}{c}\text { Średnio } \\
\text { na szkołę }\end{array}$ \\
\hline $\mathbf{1}$ & $\mathbf{2}$ & $\mathbf{3}$ & $\mathbf{4}$ \\
\hline $1841 / 42$ & 1 & 19 & 19,0 \\
\hline $1842 / 43$ & 2 & 25 & 12,5 \\
\hline
\end{tabular}

${ }^{27}$ R. Pelczar, Rzymskokatolickie szkoty trywialne w Galicji w latach 1774-1875, Lublin 2014, s. 87-92; tenże, Szkoły trywialne dla dziewcząt w tacińskiej diecezji przemyskiej w czasach zaborów, „Przegląd Historyczno-Oświatowy”, (2014) nr 1-2, s. 20-41.

${ }^{28}$ Szematyzm szkót ludowych i ich nauczycieli pod kierunkiem konsystorza przemyskiego obrz. tac. na rok 1865, Jasło 1864, s. 18. 


\begin{tabular}{|c|c|c|c|}
\hline 1 & 2 & 3 & 4 \\
\hline $1843 / 44$ & 2 & 33 & 16,5 \\
\hline $1844 / 45$ & 2 & 25 & 12,5 \\
\hline $1845 / 46$ & 2 & 32 & 16,0 \\
\hline $1846 / 47$ & 4 & 58 & 14,5 \\
\hline $1847 / 48$ & 1 & 14 & 14,0 \\
\hline $1848 / 49$ & 2 & 33 & 16,5 \\
\hline $1849 / 50$ & 3 & 35 & 11,7 \\
\hline $1850 / 51$ & 3 & 42 & 14,0 \\
\hline $1851 / 52$ & 3 & 38 & 12,7 \\
\hline $1852 / 53$ & 4 & 48 & 12,0 \\
\hline $1853 / 54$ & 4 & 57 & 14,2 \\
\hline $1854 / 55$ & 5 & 69 & 13,8 \\
\hline $1855 / 56$ & 3 & 48 & 16,0 \\
\hline $1856 / 57$ & 2 & 36 & 18,0 \\
\hline $1857 / 58$ & 3 & 52 & 17,3 \\
\hline $1858 / 59$ & 4 & 63 & 15,7 \\
\hline $1859 / 60$ & 4 & 72 & 18,0 \\
\hline $1860 / 61$ & 3 & 66 & 22,0 \\
\hline $1861 / 62$ & 4 & 48 & 12,0 \\
\hline $1862 / 63$ & 5 & 71 & 14,2 \\
\hline $1863 / 64$ & 5 & 104 & 20,8 \\
\hline $1864 / 65$ & 6 & 114 & 19,0 \\
\hline $1865 / 66$ & 5 & 98 & 19,6 \\
\hline $1866 / 67$ & 5 & 97 & 19,4 \\
\hline $1867 / 68$ & 2 & 44 & 22,0 \\
\hline
\end{tabular}

Uwaga: w tabeli uwzględniono wyłącznie zakłady z podaną liczbą uczennic.

Źródło: Szematyzmy szkót ludowych $w$ diecezji przemyskiej obrz. łac. na lata 1842-1868, passim. 
Tabela 11. Liczebność uczennic w konwiktach na terenie diecezji tarnowskiej w latach 1844-1864 (wykaz niepelny)

\begin{tabular}{|c|c|c|c|c|}
\hline $\begin{array}{c}\text { Rok } \\
\text { szkolny }\end{array}$ & Miasto & $\begin{array}{l}\text { Wlaścicielka } \\
\text { zakładu }\end{array}$ & $\begin{array}{l}\text { Liczba } \\
\text { uczennic }\end{array}$ & Źródło \\
\hline $1844 / 45$ & Tarnów & $\begin{array}{l}\text { Konstancja Szymańska } \\
\text { Konstancja Łazowska }\end{array}$ & $\begin{array}{l}15 \\
15\end{array}$ & Szematyzm (...) 1845 , s. 5 \\
\hline $1847 / 48$ & Tarnów & $\begin{array}{l}\text { Konstancja Szymańska } \\
\text { Konstancja Łazowska }\end{array}$ & $\begin{array}{c}4 \\
14\end{array}$ & Szematyzm (...) 1848 , s. 5 \\
\hline $1849 / 50$ & Tarnów & Konstancja Łazowska & 5 & Szematyzm (...) 1850, s. 9 \\
\hline $1851 / 52$ & Tarnów & Konstancja Łazowska & 12 & Szematyzm (...) 1852, s. 9 \\
\hline $1852 / 53$ & Tarnów & Konstancja Łazowska & 24 & Szematyzm (...) 1853, s. 9 \\
\hline $1862 / 63$ & Podgórze & Agnieszka Jałbrzykowska & 26 & Szematyzm (...) 1863, s. 50 \\
\hline $1863 / 64$ & $\begin{array}{l}\text { Tarnów } \\
\text { Podgórze }\end{array}$ & $\begin{array}{l}\text { Paulina Łazowska } \\
\text { Agnieszka Jałbrzykowska }\end{array}$ & $\begin{array}{l}29 \\
25\end{array}$ & Szematyzm (...) 1864, s. 73 \\
\hline
\end{tabular}

Źródło: Szematyzmy szkół ludowych diecezji tarnowskiej obrz. łac. na lata 1845-1864, passim.

Warto zastanowić się nad skalą działalności edukacyjno-wychowawczej tytułowych placówek. Kwestię tę można przeanalizować jedynie na przykładzie zakładów z diecezji przemyskiej. Jak wynika z tabeli 10, corocznie w omawianych placówkach edukowało się łącznie od ok. 20 do ponad 110 dziewcząt. Nie były to więc duże grupy. Widoczne jest przy tym zjawisko dość znacznych corocznych zmian liczbowych uczennic, co było związane z dużą fluktuacją placówek i ich niestabilnością w zakresie funkcjonowania. Średnio w danym roku w jednej placówce przebywało po kilkanaście uczennic. Wyjątkiem jest rok szkolny 1860/1861, gdzie przeciętnie w jednym zakładzie edukowały się 22 panny. Dopiero od roku szkolnego 1863/1864 średnia zaczęła oscylować wokół liczby 20, a w ostatnim roku uwzględnionym w tabeli wyniosła nawet 22 osoby.

Należy na koniec zauważyć, że kwestię funkcjonowania prywatnych szkół i zakładów naukowo-wychowawczych uporządkował dopiero dekret Ministerstwa Wyznań i Oświecenia z 2 października 1858 r. Według niego

zakłady prywatne do nauki i wychowania młodzieży są albo szkołami prywatnymi albo zakładami prywatnymi naukowo-wychowawczymi. Pierwsze zajmują się właściwie nauczaniem, a wychowaniem tylko o tyle, o ile do tego 
i szkoły publiczne są obowiązane; drugie prócz nauczania starają się o wychowanie w całej objętości i dlatego powierzoną sobie młodzież na mieszkanie i stół przyjmują ${ }^{29}$.

\section{Wnioski}

Omawiane placówki edukacyjno-wychowawcze dla dziewcząt powstawały w większych miastach Galicji. W okresie lat 1841-1870 w Galicji utworzono 55 prywatnych zakładów kształcenia panien. W Galicji najwięcej tych placówek zorganizowano we Lwowie (18). Najczęstszą formą były konwikty (pensje). Powszechnie tworzono je w miastach diecezji przemyskiej oraz tarnowskiej. Jedynie $\mathrm{w}$ archidiecezji lwowskiej, a konkretnie we Lwowie, oprócz nich organizowano także szkoły. Większość placówek edukacyjnych zlokalizowano w miastach cyrkularnych (obwodowych). Reszta działała w siedzibach okręgów (dystryktów) oraz powiatów. Prawnie podlegały one nadzorowi państwowych władz oświatowych oraz rzymskokatolickich władz diecezjalnych. Okres działalności tych zakładów był bardzo zróżnicowany. Ich organizatorkami i właścicielkami były wyłącznie kobiety, przeważnie Polki. Dużą ich grupę stanowiły także cudzoziemki. Właścicielki zakładów dodatkowo pełniły funkcję nauczycielek i wychowawczyń. Najczęściej czyniły to samodzielnie. Tylko czasami zatrudniały dodatkowych nauczycieli. Natomiast funkcjonowała powszechna praktyka angażowania do nauczania religii miejscowych księży katolickich. Do tych instytucji przyjmowano nieduże grupy dziewcząt. Zazwyczaj było ich po kilkanaście lub niewiele więcej.

\section{REFERENCES / BIBLIOGRAFIA}

\section{Źródła}

Dekret c. k. ministerstwa oświecenia z dnia 2. Października 1858. L. 1244. dotyczacy szkót prywatnych, jako też zakładów naukowo-wychowawczych prywatnych $w$ obrębie szkoty ludowej, „Kurenda Szkolna” (krakowska), (1863) nr 5, s. 40; nr 6, s. 43-48.

Status scholarum nationalium in dioecesi Premisliensi Ritus Latini Anno 1842, Przemyśl 1842.

Status scholarum nationalium in dioecesi Premisliensi Ritus Latini Anno 1843, Przemyśl 1843.

Schematismus der Volksschulen und des Lehrpersonals in der Przemysler Lat. Diöcese für das Jahr 1844, Przemyśl 1843.

Schematismus der Volksschulen und des Lehrpersonals in der Przemysler lat. Dioecese für das Jahr 1845, Przemyśl 1844.

Schematismus der Volksschulen und des Lehrpersonals in der Przemysler Dioecese für das Jahr 1846, Przemyśl 1845.

${ }^{29}$ Dekret c. k. ministerstwa oświecenia z dnia 2. Października 1858. L. 1244. dotyczacy szkót prywatnych, jako też zakładów naukowo-wychowawczych prywatnych $w$ obrębie szkoty ludowej, „Kurenda Szkolna” (krakowska) (1863) nr 5, s. 40. 
Schematismus der Volks-Schulen und des Lehrpersonals in der Przemyśler Diöcese lat. Ritus für das Jahr 1847, Rzeszów 1847.

Schematismus der Volks-Schulen und des Lehrpersonals in der Przemyśler Diöcese lat. Ritus für das Jahr 1848, Rzeszów 1848.

Szematyzm szkót ludowych $i$ ich nauczycieli znajdujacych się $w$ diecezji przemyskiej o. t. na rok 1849, Rzeszów 1849.

Szematyzm szkół ludowych i ich nauczycieli pod kierunkiem konsystorza przemyskiego obrz. tac. na rok 1850, Przemyśl 1850.

Szematyzm szkół ludowych i ich nauczycieli pod kierunkiem konsystorza przemyskiego obrz. łac. na rok 1851, Przemyśl 1851.

Szematyzm szkół ludowych i ich nauczycieli pod kierunkiem konsystorza przemyskiego obrz. łac. na rok 1852, Przemyśl 1852.

Szematyzm szkół ludowych i ich nauczycieli pod kierunkiem konsystorza przemyskiego obrz. łac. na rok 1853, Przemyśl 1853.

Szematyzm szkót ludowych i ich nauczycieli pod kierunkiem konsystorza przemyskiego obrz. łac. na rok 1854, Przemyśl 1854.

Szematyzm szkół ludowych i ich nauczycieli pod kierunkiem konsystorza przemyskiego obrz. łac. na rok 1855, Przemyśl 1855.

Szematyzm szkół ludowych i ich nauczycieli pod kierunkiem konsystorza przemyskiego obrz. łac. na rok 1856, Przemyśl 1856.

Szematyzm szkót ludowych i ich nauczycieli pod kierunkiem konsystorza przemyskiego obrz. łac. na rok 1857, Przemyśl 1857.

Szematyzm szkół ludowych i ich nauczycieli pod kierunkiem konsystorza przemyskiego obrz. łac. na rok 1858, Przemyśl 1858.

Szematyzm szkół ludowych i ich nauczycieli pod kierunkiem konsystorza przemyskiego obrz. łac. na rok 1859, Przemyśl 1859.

Szematyzm szkół ludowych i ich nauczycieli pod kierunkiem konsystorza przemyskiego obrz. łac. na rok 1860, Jasło 1859.

Szematyzm szkót ludowych i ich nauczycieli pod kierunkiem konsystorza przemyskiego obrz. łac. na rok 1861, Jasło 1860.

Szematyzm szkół ludowych i ich nauczycieli pod kierunkiem konsystorza przemyskiego obrz. tac. na rok 1862, Jasło 1861.

Szematyzm szkół ludowych i ich nauczycieli pod kierunkiem konsystorza przemyskiego obrz. tac. na rok 1863, Jasło 1862.

Szematyzm szkół ludowych i ich nauczycieli pod kierunkiem konsystorza przemyskiego obrz. tac. na rok 1864, Jasło 1863.

Szematyzm szkół ludowych i ich nauczycieli pod kierunkiem konsystorza przemyskiego obrz. łac. na rok 1865, Jasło 1864.

Szematyzm szkół ludowych i ich nauczycieli pod kierunkiem konsystorza przemyskiego obrz. łac. na rok 1866, Jasło 1865.

Szematyzm szkół ludowych i ich nauczycieli pod kierunkiem konsystorza przemyskiego obrz. łac. na rok 1867, Jasło 1866.

Szematyzm szkót ludowych i ich nauczycieli pod kierunkiem konsystorza przemyskiego obrz. łac. na rok 1868, Jasło 1867.

Schematismus des Gesammten an den Volksschulen der Tarnower Bischöflichen Diöcese l. R. Angestelten Lehrpersonals, für das Jahr 1845, Tarnów [1845].

Szematyzm obejmujacy wszystkich nauczycieli przy szkołach narodowych $w$ tarnowskiej dyecezyi biskupiej obrządku łacińskiego znajdujacych się na rok 1848, Tarnów [1848]. 
Szematyzm obejmujacy wszystkich nauczycieli przy szkołach narodowych $w$ tarnowskiej dyecezyi biskupiej obrządku łacińskiego znajdujących się na rok 1850, Tarnów [1850].

Szematyzm obejmujacy wszystkich nauczycieli przy szkołach narodowych $w$ tarnowskiej dyecezyi biskupiej obrządku łacińskiego znajdujących się na rok 1852, Tarnów [1852].

Szematyzm obejmujacy wszystkich nauczycieli przy szkołach narodowych $w$ tarnowskiej dyecezyi biskupiej obrzadku łacińskiego znajdujacych się na rok 1853, Tarnów [1853].

Schematismus des Gesammten an den Volksschulen der Tarnower Bischöflichen Diöcese l. R. Angestelten Lehrpersonals, für das Jahr 1855, Tarnów [1855].

Schematismus des Gesammten an den Volksschulen der Tarnower Bischöflichen Diöcese l. R. Angestelten Lehrpersonals, für das Jahr 1856, Tarnów [1856].

Szematyzm obejmujacy wszystkich nauczycieli przy szkołach narodowych $w$ tarnowskiej dyecezyi biskupiej obrządku łacińskiego znajdujacych się na rok 1862, Tarnów 1862.

Szematyzm obejmujacy wszystkich nauczycieli przy szkołach narodowych $w$ tarnowskiej dyecezyi biskupiej obrzadku łacińskiego znajdujacych się na rok 1863, Tarnów 1862.

Szematyzm obejmujący wszystkich nauczycieli przy szkołach narodowych $w$ tarnowskiej dyecezyi biskupiej obrządku łacińskiego znajdujacych się na rok 1864, Tarnów 1863.

Szematyzm obejmujacy wszystkich nauczycieli przy szkołach narodowych $w$ tarnowskiej dyecezyi biskupiej obrządku łacińskiego znajdujacych się na rok 1865, Tarnów 1864.

Szematyzm szkół ludowych i ich nauczycieli w tarnowskiej dyecezyi na rok 1866, Tarnów 1865.

Szematyzm szkół ludowych i ich nauczycieli w tarnowskiej dyecezyi na rok 1867, Tarnów 1866.

Szematyzm szkół ludowych i ich nauczycieli w tarnowskiej dyecezyi na rok 1868, Tarnów 1867.

Szematyzm szkół ludowych i ich nauczycieli w tarnowskiej dyecezyi na rok 1869, Tarnów 1868.

Szematyzm szkół ludowych i ich nauczycieli w tarnowskiej dyecezyi na rok 1870, Tarnów 1869.

Szematyzm szkół ludowych zostających pod nadzorem lwowskiego konsystorza metropolitalnego obrz. łac. na rok 1861, Lwów 1861.

Szematyzm szkół ludowych zostających pod nadzorem lwowskiego konsystorza metropolitalnego obrz. łac. na rok 1862, Lwów 1862.

Szematyzm szkół ludowych zostających pod nadzorem lwowskiego konsystorza metropolitalnego obrz. łac. na rok 1864, Lwów 1864.

Szematyzm szkół ludowych zostających pod nadzorem lwowskiego konsystorza metropolitalnego obrz. łac. na rok 1865, Lwów 1865.

Szematyzm szkół ludowych zostających pod nadzorem lwowskiego konsystorza metropolitalnego obrz. łac. na rok 1866, Lwów 1866.

Szematyzm szkół ludowych zostających pod nadzorem lwowskiego konsystorza metropolitalnego obrz. łac. na rok 1867, Lwów 1867.

\section{Opracowania}

Chodynicki Ignacy, Historia stołecznego królestw Galicji i Lodomeryi miasta Lwowa od założenia jego aż do czasów teraźnieyszych, Lwów 1829.

Dobrowolska Mieczysława, Początki szkolnictwa dla dziewcząt, w: Historia wychowania, red. Ł. Kurdybacha, t. 2, Warszawa 1967, s. 188-198.

Dormus Katarzyna, Włoch Anna, Wojniak Justyna, Edukacja kobiet, kobiety w edukacji. Szkice historyczno-pedagogiczne, Kraków 2017. 
Falkowska Joanna, W stużbie edukacji kobiet. Działalność Felicji Boberskiej z Wasilewskich (1825-1889), „Studia Paedagogica Ignatiana”, 19 (2016) nr 3, s. 123-142.

Felczyński Zygmunt, Rozwój kulturalny Przemyśla 1772-1918, w: Tysiac lat Przemyśla. Zarys historyczny, cz. 2, red. F. Persowski, A. Kunysz, J. Olszak, Warszawa-Kraków 1974, s. 149-184.

Gaj-Piotrowski Wilhelm, Stan szkolnictwa i oświaty w rejonie Rozwadowa w latach 17721874, „Rocznik Województwa Rzeszowskiego”, 8 (1975) s. 23-56.

Janicka Małgorzata, Edukacja kobiet na ziemiach polskich na przełomie XVIII i XIX wie$k u$, Warszawa 2017 (zamieszczona w Internecie praca doktorska), https://depotuw. ceon.pl/handle/item/2527 (dostęp: 23.12.2019).

M. W. [Michał Wiesiołowski], Rys statystyczno-jeograficzny Galicyi Austrjackiej, Poznań 1842.

Majorek Czesław, Marmon Wacław, Oświata i kultura regionu tarnowskiego w okresie rozbiorów i niewoli, w: Tarnów. Dzieje miasta i regionu, t. 2: Czasy rozbiorów i Drugiej Rzeczypospolitej, red. F. Kiryk, Z. Ruta, Tarnów 1983, s. 259-286.

Ochenduszko Tadeusz, Dymnicki Feliks (1824-1876), w: Słownik biograficzny twórców oświaty i kultury XIX i XX wieku Polski potudniowo-wschodniej, red. A. Meissner, K. Szmyd, Rzeszów 2011, s. 103-104.

Pelczar Roman, Szkoly trywialne dla dziewczą w tacińskiej diecezji przemyskiej w czasach zaborów, „Przegląd Historyczno-Oświatowy”, (2014) nr 1-2, s. 20-41.

Pelczar Roman, Rzymskokatolickie szkoty trywialne w Galicji w latach 1774-1875, Lublin 2014.

Persowski Franciszek, Kartki z dziejów szkolnictwa w Galicji w I połowie XIX w. (głównie z terenu województwa rzeszowskiego), „Rocznik Naukowo-Dydaktyczny WSP w Rzeszowie", z. 4: Nauki Pedagogiczne, (1967) s. 387-415.

Quirini-Popławska Danuta, Szkolnictwo krośnieńskie od XVII w. do 1914 r., w: Krosno. Studia z dziejów miasta i regionu, t. 2: 1918-1970, red. J. Garbacik, Kraków 1973, s. 332-362.

Rzemieniuk Florentyna, Unickie szkoły poczatkowe w Galicji w latach 1805-1914, „Rozprawy z Dziejów Oświaty", 33 (1990) s. 107-149.

Selingerowa Julia, Obowiązki kobiety każdego stanu w zakresie gospodarstwa domowego, Lwów 1882.

Świeboda Józef, Dzieje I Gimnazjum w Rzeszowie 1786-1918, Rzeszów 1984.

Świeboda Józef, Szkolnictwo ludowe w Rzeszowie pod zaborem austriackim (1772-1918), „Rocznik Województwa Rzeszowskiego”, 9 (1978) s. 5-37.

Wlaźlik Barbara, Historyczny wymiar edukacji dziewczat, „Prace Naukowe Akademii im. Jana Długosza w Częstochowie”. Seria: Pedagogika, 15 (2006) s. 211-226.

Z[ofia] R[Romanowiczówna], Felicya z Wasilewskich Boberska. Życiorys, Lwów 1893.

Zięba-Kołodziej Beata, Internat i bursa. Historia i współczesność, Tarnobrzeg 2011.

\section{Netografia}

Motyka Andrzej, Dymnicki Feliks (1824-1876), w: Diecezja Rzeszowska, www2.diecezja.rzeszow.pl/?q=node/1914 (dostęp: 10.04.2020).

Pensja, http://czasemancypantek.pl/w-spoleczenstwie/edukacja/36-pensja(dostęp: 10.04.2020). 


\title{
PRIVATE INSTITUTIONS FOR THE EDUCATION AND UPBRINGING OF GIRLS IN GALICIA (EASTERN EUROPE) FROM 1841 TO 1870 (IN THE LIGHT OF DIOCESAN YEARBOOKS OF FOLK SCHOOLS)
}

\begin{abstract}
The aim of the article is to present the problem of educating girls from noble and middle-class families living in Galicia in the 19th century. They were often sent to private educational institutions opened in larger towns and cities of the area. Although the problem concerns the Austrian Partition, it can also be considered in the context of other Polish lands during the Partitions era. For this article, mainly printed diocesan lists (yearbooks) of folk schools from the area of Galicia were used. Educational institutions for girls operated by private persons were analysed. Most institutions of this type were established in Lviv. The period of their activity varied considerably. The founders and owners of these institutions were women. Moreover, they acted as teachers. Predominantly they taught on their own. Only occasionally were additional teachers employed in some establishments. It was common practice to employ local priests to teach the Catholic religion. Small groups of girls were admitted to these institutions. Usually there were a dozen or a few more.
\end{abstract}

Keywords: schools for girls; education in Galicia; education of girls; yearbooks; Galicia 